\title{
Are prohexadione calcium and Pseudomonas fluorescens a solution to limit the spread of annual bluegrass (Poa annua $\mathrm{L}$. .) on football pitches?
}

\author{
Tanja Bohinc, Barbara Zanelli, Matej Vidrih, Stanislav Trdan*
}

Department of Agronomy, Biotechnical Faculty, University of Ljubljana, Jamnikarjeva 101, SI-1000 Ljubljana, Slovenia

\begin{abstract}
In 2020, a greenhouse experiment was conducted to investigate the suppression of annual bluegrass (Poa annua), which is a difficult weed to manage in cool-season in turfgrass mixtures on football pitches. The efficacy of prohexadione calcium (Pc), ethephon (Eth) and Pseudomonas fluorescens against P. annua, Lolium perenne and Poa pratensis was tested, as the latter two most commonly occur in turfgrass mixtures on football pitches. Mesotrione (Mes) was used as a positive control, and nontreated grass was used as a negative control. Only a single grass species was sown in each pot. Treatments were randomly distributed for two experiments conducted separately: first - unmown grass before the beginning of spraying and second - grass mowed before the beginning of spraying. In both experiments, plant height and the number of tillers were measured/counted several times during the growing season. In both experiments, grasses were sprayed six times with Pc, Eth and P. fluorescens, while Mes was applied twice. Based on the performed study, the efficacy of the tested products is connected to grass species and whether the grass was mowed/cut before spraying. It has been detected in the present study that spraying with Pc could reduce the height of annual bluegrass, while spraying with $P$. fluorescens has reduced the number of tillers. Spraying was more effective on grasses that were mowed/cut before the beginning of spraying. Mes should cause severe damage to annual bluegrass but without confirmation in this study. Results of this study have indicated that the application of Pc and P. fluorescens can inhibit the spread of annual bluegrass in football pitches; however, testing their effectiveness against $P$. апnиa under field conditions should be performed as well.
\end{abstract}

Keywords: annual bluegrass, ethephon, Kentucky bluegrass, mesotrione, perennial ryegrass, prohexadione calcium, Pseudomonas fluorescens

\section{INTRODUCTION}

Turfgrasses are important for human activities from functional, recreational and ornamental standpoints. Sport turfgrass plays an especially important role by providing desirable characteristics for each sport and reducing injuries to the participants (Kamal-Uddin et al., 2009). These characteristics can be broken down into visual qualities (attractive green colour, leaf texture, density and uniformity) and functional qualities (stiffness, elasticity, resilience, performance, verdure, rooting and resilience) (Cirera, 2013).

A weed is a plant growing in an undesired location. It can be any plant that grows or reproduces aggressively or is outside its native habitat (Paikekari et al., 2016). Rapid weed propagation, especially of annual bluegrass

\footnotetext{
*Corresponding author.

e-mail: stanislav.trdan@bf.uni-lj.si (Stanislav Trdan).
} 
(Poa annua L.), is a major issue for ornamental and sports turfgrass management (Parra et al., 2020). Weeds compete with the desired turfgrasses for environmental resources such as nutrients, sunlight and water (Yu et al., 2019). This can result in reduced turf growth or increase the presence of other pests or diseases, making the surroundings unsuitable for turf growth (Kamal-Uddin et al., 2009).

Annual bluegrass is one of the main weeds of sport turfgrasses, especially in football pitches. Because of its prolific seed production and germination coupled with tolerance to low mowing heights and soil compaction, annual bluegrass is a very invasive weed (Skelton et al., 2012). In general, the presence of weeds on football pitches disrupts the uniformity and playability due to the variability in leaf width, colour and growth habit, and so these weeds must be eliminated from turfgrass areas to enrich the aesthetic quality of the football field (Kamal-Uddin et al., 2009). Because annual bluegrass is a weed growing on sports pitches together with other desirable turfgrass species, selective control is difficult (Kennedy, 2016). For the suppression of annual bluegrass, pre- or postemergence herbicides can be used (Glab et al., 2020).

To date, few studies on the suppression of annual bluegrass on football fields by using plant growth regulators (PGRs) have been performed in Europe (Larsen et al., 2004; Curk et al., 2017). PGRs can be divided into several groups, i.e. compounds related to auxins, gibberellins and inhibitors of gibberellin biosynthesis, cytokinins, and abscisic acid, as well as compounds affecting ethylene status (Glab et al., 2020; Petelewitz et al., 2021). Prohexadione calcium (Pc), one of the PGRs used in our study, inhibits gibberellin production in turfgrass and is mainly used to reduce the number of mowings and to suppress the seed heads of annual bluegrass (Rademacher, 2016). Ethephon (Eth), another PGR, is one of the most commonly used PGRs in vegetable and turfgrass management (Jędrszczyk et al., 2017; Zhang et al., 2018). Annual bluegrass can also be suppressed by bioherbicides, such as weed-suppressing bacteria. For example, Pseudomonas fluorescens can produce a wide range of secondary metabolites that have herbicidal activity, and in some research, it is effective in controlling annual bluegrass (Pedras et al., 2003; Harding and Raizada, 2015; Kennedy, 2016).

Since pesticides are banned on soccer pitches in the EU, there is an urgent need to find 'organic' alternatives and hence this study (Larsen et al., 2004; Aamlid et al., 2012). This study aimed to determine the effect of three PGRs and synthetic herbicides on young plants of annual bluegrass, and at the same time, the resistance of perennial ryegrass (Lolium perenne L.) and Kentucky bluegrass (Poa pratensis L.) to these substances. It is important to effectively control the weed Poa annua L. while keeping the other two species of turfgrass intact.

\section{MATERIALS AND METHODS}

\section{Greenhouse experiment}

A greenhouse experiment was carried out at the Biotechnical Faculty in Ljubljana $\left(46^{\circ} 04^{\prime} \mathrm{N}, 14^{\circ} 31^{\prime} \mathrm{E}\right.$, $299 \mathrm{~m}$ a.s.l.), Slovenia. Greenhouse temperatures at the time of the experiment were $17{ }^{\circ} \mathrm{C}$ during the day and $4{ }^{\circ} \mathrm{C}$ at night. Plants received artificial light (highpressure sodium vapour light, Osram, luminosity of light: $550 \mathrm{~nm}$, rated power: $400 \mathrm{~W}$, lighting power: $178 \mathrm{~W} \cdot \mathrm{m}^{-2}, \mathrm{CO}_{2}$ concentration by light: $500 \mathrm{ppm}$ ) between 4:00 p.m. and 8:00 p.m. and were watered in 3 days interval with tap water. The pots were arranged in a split-plot design with three replications. The experiments consisted of 450 pots with a volume of 21 , including untreated controls.

Turfgrass seeds were sown on $13^{\text {th }}$ January 2020 in pots filled with the special substrate 'Biokompovit trava' (supplier: Poljo Posavec Ltd., Croatia) for grass at a sowing rate of $0.3-0.7 \mathrm{~g} \cdot$ pot $^{-1}$, which corresponds to the following sowing rates: $10 \mathrm{~g} \cdot \mathrm{m}^{-2}$ for annual bluegrass and Kentucky bluegrass, and $35 \mathrm{~g} \cdot \mathrm{m}^{-2}$ for perennial ryegrass (Turfgrass Seed, 2016). We seeded a mixture of perennial ryegrass. cv. 'Fiesta IV' and cv. 'Rinovo' (150 pots; supplier: Semillas Fitó Barcelona Ltd., Spain), Kentucky bluegrass cv. 'Legend' (150 pots; supplier: Poljo Posavec Ltd., Croatia; producer: ICL SF Ltd., France) and a population of annual bluegrass (150 pots; supplier: Naturescape British Wildflowers Ltd, Maple Farm, Coach Gap Lane, Langar, Nottinghamshire, NG13 9HP, England). Only a single grass species was sown in each pot. The substrate for sowing ('Biokompovit trava') was a mixture of quartz sand, white and black peat, and $100 \%$ organic materials without chemical ingredients that originated from Poljo Posavec Ltd. (Croatia).

Pots were fertilised with organomineral granular NPK (nitrogen-phosphorus-potassium) fertiliser DCM Vital green 14-4-8+3 $\mathrm{MgO}+\mathrm{Fe}\left(\right.$ at $0.9 \mathrm{~g} \cdot \mathrm{pot}^{-1} ; 300 \mathrm{~kg} \cdot \mathrm{ha}^{-1}$ ) producer: DCM Ltd.; Grobbendonkmesto, Belgium) and the soil improver DCM Antagon at a rate of $4 \mathrm{~g} \cdot$ pot $^{-1}$ $\left(20 \mathrm{~kg} \cdot 100 \mathrm{~m}^{-2}\right)$. Fertilisers were obtained from Vitalis Crop Care Ltd. (Samobor, Croatia).

\section{Treatments}

Our study was divided into two different separated individual experiments. In Experiment 1, we were interested in the activity of PGRs on previously uncut grass, and in Experiment 2, we cut the grass with hand scissors (at $2.5 \mathrm{~cm}$ ) before the first spraying. Respectively, each of mentioned experiments was performed in 225 pots; namely, each of three turfgrass species was grown in 75 pots (15 pots per specific treatment, including replications in time). Respectively, five pots were included in specific treatment. In both experiments, the grasses had developed 3-4 tillers at the time of the first spraying.

In both experiments, we have tested five treatments, i.e. three PGRs and positive and negative control, i.e. 
(1) P. fluorescens $\times$ Azospirillum brasilense (product Rhizoflo Premium; applied as 2.5\% [45 ml $1.81^{-1} \mathrm{H}_{2} \mathrm{O}$ ] in manuscript marked as $\mathrm{Pf} \times A b$ ); (2) Pc $100 \mathrm{~g} \cdot \mathrm{kg}^{-1}$ (product Regalis $^{\circledR}$ Plus; applied as $3.6 \mathrm{~g} \mathrm{Regalis}^{\circledR}$ Plus + $1.89 \mathrm{~g}$ Pehacid $\cdot 1.8 \mathrm{l}^{-1} \mathrm{H}_{2} \mathrm{O}$, in manuscript marked as Pc); and (3) Eth $480 \mathrm{~g} \cdot \mathrm{l}^{-1}$ (product Baia; applied as $7.5 \mathrm{ml} \cdot 1.8 \mathrm{1}^{-1} \mathrm{H}_{2} \mathrm{O}$; in manuscript marked as Eth). Grasses in the positive control were sprayed with the herbicide Callisto ${ }^{\circledR} 480$ SC (a.i. mesotrione [Mes] $480 \mathrm{~g} \cdot \mathrm{1}^{-1}$; applied as $1.4 \mathrm{ml} \cdot 1.8 \mathrm{I}^{-1} \mathrm{H}_{2} \mathrm{O}$; in manuscript marked as Mes), while control treatment (in manuscript marked as Contr) was done only with sprayed with tap water. The biofertiliser Rhizoflo Premium is produced by $\mathrm{CKC}^{\circledR}$ Argentina SA., the plant growth regulator Regalis ${ }^{\circledR}$ Plus is produced by BASF SE Ltd. (Germany), the plant growth regulator Baia by ADAMA Agriculture B.V. Ltd. (Switzerland) and the herbicide Callisto ${ }^{\circledR} 480$ SC by Syngenta Crop Protection AG Ltd. (Switzerland). Mes, as the active substance in selected herbicide, was previously mentioned as successful against annual bluegrass encroachment by Park et al. (2019). To continue, Mes was initially labelled to use in corn production. More recently, it has been labelled to use in turfgrass production, and it is safe to use at cool-season turfgrass establishments (Venner et al., 2011).

\section{Spraying and mowing}

Spraying dates, regarding selected products and Experiments 1 and 2, are presented in Table 1. In Experiment 1, mowing was performed on $3^{\text {rd }}$ and $27^{\text {th }}$ March, while in Experiment 2, mowing was performed on $24^{\text {th }}$ February and $20^{\text {th }}$ March. Mowing of turfgrass was performed to $2.5 \mathrm{~cm}$ (Manager's Guide to Natural Grass Football Pitches, 2021).

\section{Measuring and counting}

Measuring of plant height and counting the number of tillers in Experiment 1 were carried out on the following dates: $11^{\text {th }}$ February (only plant height); $18^{\text {th }}, 21^{\text {st }}, 25^{\text {th }}$ and $28^{\text {th }}$ February; $3^{\text {rd }}, 10^{\text {th }}, 13^{\text {th }}, 17^{\text {th }}$, $20^{\text {th }}, 24^{\text {th }}, 27^{\text {th }}$ and $31^{\text {st }}$ March; and $3^{\text {rd }}, 7^{\text {th }}, 10^{\text {th }}, 14^{\text {th }}$ and $17^{\text {th }}$ April. In Experiment 2, both parameters were evaluated as follows: $28^{\text {th }}$ February; $3^{\text {rd }}, 10^{\text {th }}, 13^{\text {th }}, 17^{\text {th }}$, $20^{\text {th }}, 24^{\text {th }}, 27^{\text {th }}, 31^{\text {st }}$ March; and $3^{\text {rd }}, 7^{\text {th }}, 10^{\text {th }}, 14^{\text {th }}$, and $17^{\text {th }}$ April. The number of tillers per plant was assessed using a 9-point visual scale (BBCH MONOGRAPH, 2018), where a score of 1 represents the moment the first tiller penetrated the coleoptile, a score of 2 represents when the first tiller was unfolded, a score of 3 represents when 2 tillers were unfolded, a score of 4 represents when 3 tillers were unfolded, a score of 5 represents when 4 tillers were unfolded, and a score of 6 represents when 5 tillers were unfolded. A score of 7 marks the beginning of growth or when the first lateral tiller was detected, a score of 8 represents when two lateral tillers were detected, and a score of 9 represents when three lateral tillers were detected. The plant height was measured using a ruler in the middle of each of the pots. Counting of developed tillers was performed visually according to studied literature (Boyle et al., 2016; Tilley et al., 2019). The number of tillers was counted on five randomly selected plants in each of the pots. For purpose of calculation ratios (plant height, tiller ratio), we have divided Experiment 1 into three different periods $\left(1^{\text {st }}\right.$ period $-11^{\text {th }}$ February till $3^{\text {rd }}$ March, $2^{\text {nd }}$ period $-6^{\text {th }}$ March till $27^{\text {th }}$ March, $3^{\text {rd }}$ period $-31^{\text {st }}$ March till $17^{\text {th }}$ April) and Experiment $2\left(1^{\text {st }}\right.$ period $-24^{\text {th }}$ February till $20^{\text {th }}$ March, $2^{\text {nd }}$ period $24^{\text {th }}$ March till $17^{\text {th }}$ April).

\section{Data analysis and ratio calculation}

Analysis of variance (ANOVA) was conducted to determine the differences among different turfgrasses within treatments. Differences in plant height and number of tillers per plant were analysed with ANOVA. Before analysis, each variable was tested for homogeneity of variance, and nonhomogeneous data were $\log (Y)$ transformed before ANOVA. Significant differences $(p \leq 0.05)$ between the mean values were identified using the Student-Neuman Keuls honestly

Table 1. Spraying dates within Experiments 1 and 2.

\begin{tabular}{|c|c|c|c|c|c|c|c|c|c|c|}
\hline \multirow[t]{2}{*}{ Experiment type } & \multirow[t]{2}{*}{ Treatment } & \multicolumn{9}{|c|}{ Dates } \\
\hline & & $11^{\text {th }} \mathrm{Feb}$ & $18^{\text {th }} \mathrm{Feb}$ & $25^{\text {th }} \mathrm{Feb}$ & $3^{\text {rd }}$ Mar & $10^{\text {th }} \mathrm{Mar}$ & $17^{\text {th }} \mathrm{Mar}$ & $24^{\text {th }} \mathrm{Mar}$ & $31^{\text {st }}$ Mar & $7^{\text {th }} \mathrm{Apr}$ \\
\hline \multirow[t]{5}{*}{1} & Contr & Yes & Yes & Yes & Yes & Yes & Yes & & & \\
\hline & $P f \times A b$ & Yes & Yes & Yes & Yes & Yes & Yes & & & \\
\hline & $\mathrm{Pc}$ & Yes & Yes & Yes & Yes & Yes & Yes & & & \\
\hline & Eth & Yes & Yes & Yes & Yes & Yes & Yes & & & \\
\hline & Mes & Yes & No & Yes & No & No & No & & & \\
\hline \multirow[t]{5}{*}{2} & Contr & & & & Yes & Yes & Yes & Yes & Yes & Yes \\
\hline & $P f \times A b$ & & & & Yes & Yes & Yes & Yes & Yes & Yes \\
\hline & $\mathrm{Pc}$ & & & & Yes & Yes & Yes & Yes & Yes & Yes \\
\hline & Eth & & & & Yes & Yes & Yes & Yes & Yes & Yes \\
\hline & Mes & & & & Yes & No & Yes & No & No & No \\
\hline
\end{tabular}

Yes - spraying was performed; No - without spraying; Feb - February; Mar - March; Apr - April.

Eth, ethephon; Mes, mesotrione; Pc, prohexadione calcium. 
significant difference multiple range test. All statistical analyses were performed using Statgraphics Centurion XVI software (Statgraphics Centurion, 2009), and the results are presented as the untransformed mean \pm the standard error (SE). Plant height ratio was calculated by dividing the average height of each turfgrass species on the last date of the evaluation period with the average height of plants on the first date of the evaluation period, while the tillers ratio was calculated by dividing the average number of tillers of each turfgrass species on the last date of the evaluation period with the average number of tillers on the first date of the evaluation period (Tilley et al., 2019).

\section{RESULTS}

\section{Impact of experiment type on average plant height of turfgrass species}

We have detected a statistically significant impact of all main factors and their interactions on average plant height in Experiments 1 and 2. All values are presented in Table 2. Based on the general analysis in Experiment 1, plant height was significantly the highest in the control treatment $(5.55 \pm 0.13 \mathrm{~cm})$ and $P f \times A b$ treatment $(5.45 \pm 0.12 \mathrm{~cm})$. Significantly, the lowest average grass height was detected in the Pc treatment $(3.83 \pm 0.11 \mathrm{~cm})$, which was approximately $2 \mathrm{~cm}$ lower than in the control treatment, and in treatment sprayed with $P f \times A b$. Significantly, the lowest average plant height in Experiment 2 was recorded in the Pc treatment $(3.75 \pm 0.10 \mathrm{~cm})$, while the highest average plant height was detected in the control treatment $(5.13 \pm 0.12 \mathrm{~cm})$ and in the $P f \times A b$ treatment $(5.09 \pm 0.11 \mathrm{~cm})$. On average, plants treated with $\mathrm{Pc}$ in Experiment 2 were $1.39-1.43 \mathrm{~cm}$ lower than plants in the control treatment and plants treated with $P f \times A b$.

\section{The average plant height of turfgrass species in Experiment 1}

All main effects and their interactions, which have influenced plant height in Experiment 1, are presented in Table 3.

When annual bluegrass was exposed to Pc, an average height of $3.83 \pm 0.18 \mathrm{~cm}$ was confirmed. Additionally, an average value of $5.91 \pm 0.24 \mathrm{~cm}$ was recorded in the $P f \times A b$ treatment. The average plant height of perennial ryegrass under the Pc treatment reached $4.34 \pm 0.25 \mathrm{~cm}$, whereas a height of $5.84 \pm 0.26 \mathrm{~cm}$ was found for the control treatment. The average grass height of Kentucky bluegrass

Table 2. Repeated measures ANOVA parameters for the main effects and associated interaction for average plant height.

\begin{tabular}{|c|c|c|c|}
\hline Source between variables & df & $\mathrm{F}$ & $p$ \\
\hline All between & 30 & 41.13 & $<0.05$ \\
\hline Intercept & 1 & 33.12 & $<0.05$ \\
\hline Treatment & 4 & 61.34 & $<0.05$ \\
\hline Turfgrass species & 2 & 42.72 & $<0.05$ \\
\hline Experiment type & 1 & 14.23 & $<0.05$ \\
\hline Treatment $\times$ turfgrass species & 8 & 8.10 & $<0.05$ \\
\hline Treatment $\times$ experiment type & 4 & 0.66 & 0.053 \\
\hline Turfgrass species $\times$ experiment type & 2 & 8.26 & $<0.05$ \\
\hline Treatment $\times$ turfgrass species $\times$ experiment type & 8 & 2.03 & $<0.05$ \\
\hline \multicolumn{4}{|l|}{ Source within Experiment 1} \\
\hline Within interactions & 140 & 87.12 & $<0.05$ \\
\hline Date of evaluation & 18 & $1,749.17$ & $<0.05$ \\
\hline Treatment & 4 & 154.24 & $<0.05$ \\
\hline Turfgrass species & 2 & 197.68 & $<0.05$ \\
\hline Date of evaluation $\times$ treatment & 72 & 29.46 & $<0.05$ \\
\hline Date of evaluation $\times$ turfgrass species & 36 & 122.71 & $<0.05$ \\
\hline Treatment $\times$ turfgrass species & 8 & 132.78 & $<0.05$ \\
\hline \multicolumn{4}{|l|}{ Source within Experiment 2} \\
\hline Within interactions & 139 & 77.08 & $<0.05$ \\
\hline Date of evaluation & 19 & 154.62 & $<0.05$ \\
\hline Treatment & 4 & 142.48 & $<0.05$ \\
\hline Turfgrass species & 2 & 109.22 & $<0.05$ \\
\hline Date of evaluation $\times$ treatment & 76 & 68.22 & $<0.05$ \\
\hline Date of evaluation $\times$ turfgrass species & 38 & 45.45 & $<0.05$ \\
\hline
\end{tabular}

$\mathrm{df}$ - degrees of freedom; F - F-distribution, is a continuous probability distribution that arises frequently as the null distribution of test statistics; $p-p$-value as probability of obtaining test results at least as extreme as the results observed under the assumption that the null hypothesis is correct.

ANOVA, analysis of variance. 
Table 3. Repeated measures ANOVA parameters for the main effects and associated interactions for plant height within turfgrass species in Experiments 1 and 2 (error $\mathrm{df}=470)$.

\begin{tabular}{|c|c|c|c|c|}
\hline Experiment type & Source & $\mathrm{df}$ & $\mathrm{F}$ & $p$ \\
\hline \multirow[t]{12}{*}{1} & Sources within annual bluegrass & & & \\
\hline & Date of evaluation & 18 & 11.7 & $<0.05$ \\
\hline & Treatment & 4 & 43.3 & $<0.05$ \\
\hline & Date of evaluation $\times$ treatment & 72 & 2.9 & $<0.05$ \\
\hline & Source within perennial ryegrass & & & \\
\hline & Date of evaluation & 18 & 19.9 & $<0.05$ \\
\hline & Treatment & 4 & 50.6 & $<0.05$ \\
\hline & Date of evaluation $\times$ treatment & 72 & 2.7 & $<0.05$ \\
\hline & Source within Kentucky bluegrass & & & \\
\hline & Date of evaluation & 18 & 33.4 & $<0.05$ \\
\hline & Treatment & 4 & 17.1 & $<0.05$ \\
\hline & Date of evaluation $\times$ treatment & 72 & 8.3 & $<0.05$ \\
\hline \multirow[t]{12}{*}{2} & Source within annual bluegrass & & & \\
\hline & Date of evaluation & 15 & 245.436 & $<0.05$ \\
\hline & Treatment & 4 & 105.3 & $<0.05$ \\
\hline & Date of evaluation $\times$ treatment & 60 & 93.9 & $<0.05$ \\
\hline & Source within Lolium perenne & & & \\
\hline & Date of evaluation & 15 & 198.8 & $<0.05$ \\
\hline & Treatment & 4 & 122.1 & $<0.05$ \\
\hline & Date of evaluation $\times$ treatment & 60 & 66.3 & $<0.05$ \\
\hline & Source within Poa pratensis & & & \\
\hline & Date of evaluation & 15 & 148.5 & $<0.05$ \\
\hline & Treatment & 4 & 163.8 & $<0.05$ \\
\hline & Date of evaluation $\times$ treatment & 60 & 8.3 & $<0.05$ \\
\hline
\end{tabular}

$\mathrm{df}$ - degrees of freedom; F - F-distribution, is a continuous probability distribution that arises frequently as the null distribution of test statistics; $p-p$-value as probability of obtaining test results at least as extreme as the results observed under the assumption that the null hypothesis is correct.

ANOVA, analysis of variance.

ranged from $3.51 \pm 0.16 \mathrm{~cm}$ in the Mes treatment to $5.19 \pm 0.18 \mathrm{~cm}$ in the control treatment. For the Pc and Eth treatments, the average grass heights were $3.31 \pm 0.09 \mathrm{~cm}$ and $3.56 \pm 0.11 \mathrm{~cm}$, respectively.

On the first evaluation date ( $11^{\text {th }}$ February), the average plant height in annual bluegrass treatment was ranging from $5.44 \pm 0.22 \mathrm{~cm}$ in Eth treatment to $4.92 \pm 0.30$ in Contr treatment. On $6^{\text {th }}$ March, the highest average plant height was recorded in $P f \times A b$ treatment $(4.1 \pm 0.11 \mathrm{~cm})$. On the last evaluation date ( $17^{\text {th }}$ April), the average plant height was significantly the lowest in Pc treatment $(2.60 \pm 0.10 \mathrm{~cm})$. All values are presented in Figure 1.

At the start of the evaluation period ( $11^{\text {th }}$ February), there was no significant difference detected between the five treatments on perennial ryegrass. On the first evaluation date after the first mowing, the average plant height was the lowest among all treatments. Suppression of plant growth by Mes was detected after $27^{\text {th }}$ March. All values are presented in Figure 2.

When Kentucky bluegrass was exposed to five different treatments during the growing period, the average plant height was the highest 3 days after first mowing, ranging from $3.90 \pm 0.17 \mathrm{~cm}$ at Contr treatment to $2.50 \pm 0.10 \mathrm{~cm}$ at Mes treatment. When
Kentucky bluegrass was sprayed with Pc, growing stopped after second mowing. All values are presented in Figure 3.

\section{The average plant height of turfgrass species in Experiment 2}

All main effects and their interactions, which have influenced plant height in Experiment 2, are presented in Table 3. We detected an average plant height of $3.86 \pm 0.27 \mathrm{~cm}$ for Kentucky bluegrass, $3.86 \pm 0.17 \mathrm{~cm}$ for perennial ryegrass, and $3.81 \pm 0.15 \mathrm{~cm}$ for annual bluegrass when plants were exposed to Pc treatment.

The average plant height of annual bluegrass was the highest on Contr treatment during first and second mowing, ranging from $5.10 \pm 0.15 \mathrm{~cm}$ on $28^{\text {th }}$ February to $8.10 \pm 0.15 \mathrm{~cm}$ on $20^{\text {th }}$ March. After second mowing, the average plant height of annual bluegrass did not reach $>2.5 \mathrm{~cm}$. Detailed values are presented in Figure 4 .

After first mowing till second mowing, the average plant height of perennial ryegrass reached the highest values when sprayed with $P f \times A b$. After the second mowing, the highest average plant height was recorded on $3^{\text {rd }}$ April $(5.00 \pm 0.11 \mathrm{~cm})$ at Eth treatment and did not grow additionally till the end of the experiment. All detailed values are presented in Figure 5. 


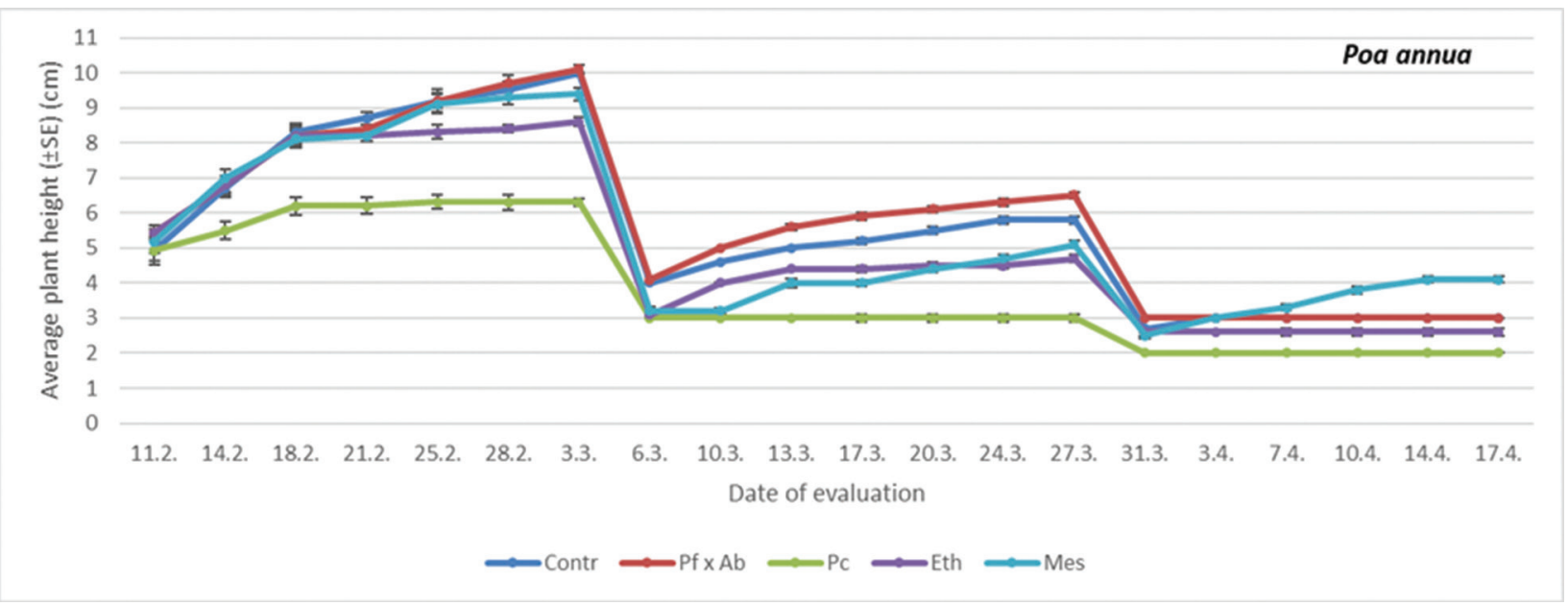

Figure 1. The average plant height on annual bluegrass treated with different PGRs. Within each evaluation date, comparison was done between different treatment (PGRs; Student-Neuman Keuls at $p=0.05$ ). For comparisons within dates, $\mathrm{df}=4.24\left(11^{\text {th }}\right.$ February, $\mathrm{F}=0.62, p=0.6526 ; 14^{\text {th }}$ February, $\mathrm{F}=7.41, p<0.05 ; 18^{\text {th }}$ February, $\mathrm{F}=27.76, p<0.05$; $21^{\text {st }}$ February, $\mathrm{F}=52.00, p<0.05 ; 25^{\text {th }}$ February, $\mathrm{F}=110.50, p<0.05 ; 28^{\text {th }}$ February, $\mathrm{F}=122.37, p<0.05 ; 3^{\text {rd }}$ March, $\mathrm{F}=84.03, p<0.05 ; 6^{\text {th }}$ March, $\mathrm{F}=39.57, p<0.05 ; 10^{\text {th }}$ March, $\mathrm{F}=18.10, p<0.05 ; 13^{\text {th }}$ March, $\mathrm{F}=16.61, p<0.05$; $17^{\text {th }}$ March, $\mathrm{F}=16.10, p<0.05 ; 20^{\text {th }}$ March, $\mathrm{F}=23.81, p<0.05 ; 24^{\text {th }}$ March, $\mathrm{F}=4.44, p<0.05 ; 27^{\text {th }}$ March, $\mathrm{F}=45.97$, $p<0.05 ; 31^{\text {st }}$ March, $\mathrm{F}=26.60, p<0.05 ; 3^{\text {rd }}$ April, $\mathrm{F}=96.00 ; 7^{\text {th }}$ April, $\mathrm{F}=50.40, p<0.05 ; 10^{\text {th }}$ April, $\mathrm{F}=86.40$, $p<0.05 ; 17^{\text {th }}$ April, $\left.\mathrm{F}=65.33, p<0.05\right)$. df, degrees of freedom; Eth, ethephon; F, F-distribution; Mes, mesotrione; Pc, prohexadione calcium; PGRs, plant growth regulators; SE, standard error.

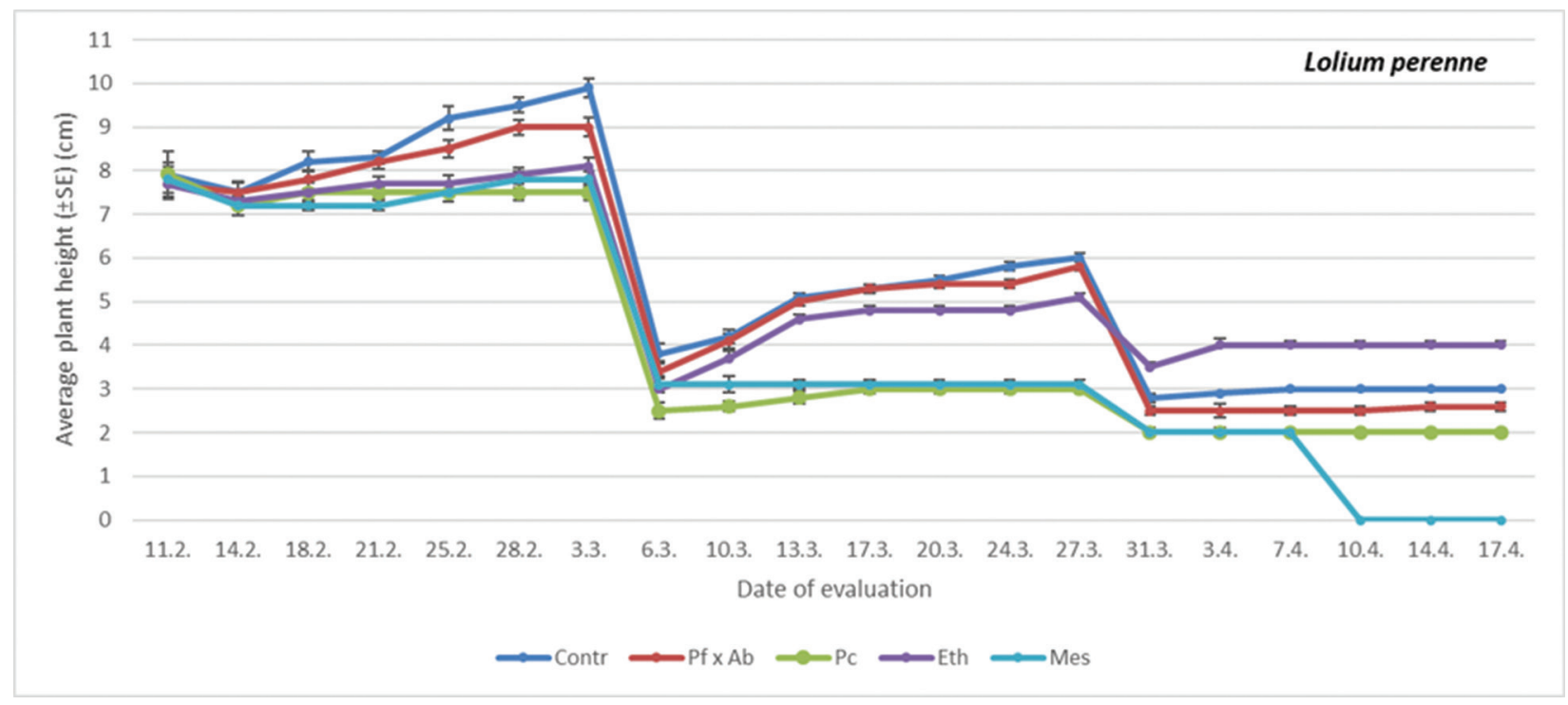

Figure 2. The average plant height on perennial ryegrass treated with different PGRs. Within each evaluation date, a comparison was done between different treatments (PGRs; Student-Neuman Keuls at $p=0.05$ ). For comparisons within dates, $\mathrm{df}=4.24\left(11^{\text {th }}\right.$ February, $\mathrm{F}=0.08, p=0.9862 ; 14^{\text {th }}$ February, $\mathrm{F}=0.79, p=0.5435 ; 18^{\text {th }}$ February, $\mathrm{F}=5.96$, $p<0.05 ; 21^{\text {st }}$ February, $\mathrm{F}=18.08, p<0.05 ; 25^{\text {th }}$ February, $\mathrm{F}=26.76, p<0.05 ; 28^{\text {th }}$ February, $\mathrm{F}=49.53, p<0.05$; $3^{\text {rd }}$ March, $\mathrm{F}=35.67, p<0.05 ; 6^{\text {th }}$ March, $\mathrm{F}=6.30, p<0.05 ; 10^{\text {th }}$ March, $\mathrm{F}=18.10, p<0.05 ; 13^{\text {th }}$ March, $\mathrm{F}=26.98$, $p<0.05 ; 17^{\text {th }}$ March, $\mathrm{F}=26.37, p<0.05 ; 20^{\text {th }}$ March, $\mathrm{F}=22.43, p<0.05 ; 24^{\text {th }}$ March, $\mathrm{F}=18.80, p<0.05 ; 27^{\text {th }}$ March, $\mathrm{F}=16.65, p<0.05 ; 31^{\text {st }}$ March, $\mathrm{F}=111.00, p<0.05 ; 3^{\text {rd }}$ April, $\mathrm{F}=140.00, p<0.05 ; 7^{\text {th }}$ April, $\mathrm{F}=50.40, p<0.05 ;$ $10^{\text {th }}$ April, $\mathrm{F}=116.67, p<0.05 ; 17^{\text {th }}$ April, $\left.\mathrm{F}=80.76, p<0.05\right) . \mathrm{df}$, degrees of freedom; Eth, ethephon; $\mathrm{F}$, F-distribution; Mes, mesotrione; Pc, prohexadione calcium; PGRs, plant growth regulators; SE, standard error.

We have detected that average plant height at Kentucky bluegrass stands out through the entire growing season, where the grass was sprayed with Pf $\times A b$ and at Contr treatment. When sprayed with $P f \times A b$, the average plant height was ranging from
$7.30 \pm 0.15 \mathrm{~cm}$ on $6^{\text {th }}$ March to $8.00 \pm 0.15 \mathrm{~cm}$ on $20^{\text {th }}$ March. After mowing, the average plant height was ranging from $2.50 \pm 0.15 \mathrm{~cm}$ after days after mowing to $4.60 \pm 0.10 \mathrm{~cm}$ on $10^{\text {th }}$ April. Detailed values are presented in Figure 6. 


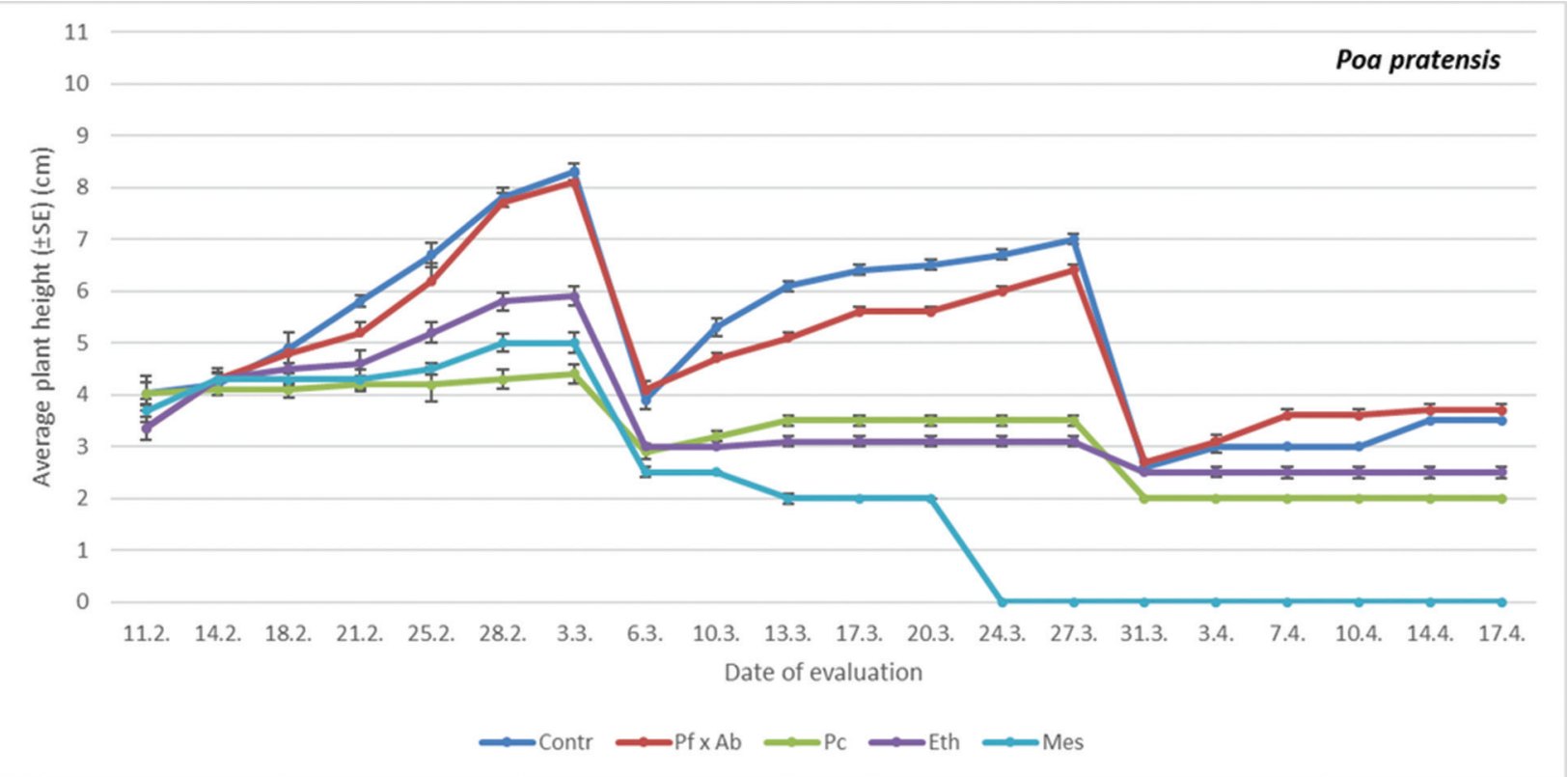

Figure 3. The average plant height in Kentucky treated with different PGRs. Within each evaluation date, a comparison was done between different treatments (PGRs; Student-Neuman Keuls at $p=0.05$ ). For comparisons within dates, $\mathrm{df}=4.24\left(11^{\text {th }}\right.$ February, $\mathrm{F}=2.23, p=0.1020 ; 14^{\text {th }}$ February, $\mathrm{F}=0.57, p=0.6864 ; 18^{\text {th }}$ February, $\mathrm{F}=7.47, p<0.05$; $21^{\text {st }}$ February, $\mathrm{F}=18.83, p<0.05 ; 25^{\text {th }}$ February, $\mathrm{F}=27.45, p<0.05 ; 28^{\text {th }}$ February, $\mathrm{F}=67.49, p<0.05 ; 3^{\text {rd }}$ March, $\mathrm{F}=109.41, p<0.05 ; 6^{\text {th }}$ March, $\mathrm{F}=78.67, p<0.05 ; 10^{\text {th }}$ March, $\mathrm{F}=75.42, p<0.05 ; 13^{\text {th }}$ March, $\mathrm{F}=102.62, p<0.05$; $17^{\text {th }}$ March, $\mathrm{F}=107.32, p<0.05 ; 20^{\text {th }}$ March, $\mathrm{F}=143.46, p<0.05 ; 24^{\text {th }}$ March, $\mathrm{F}=73.35, p<0.05 ; 27^{\text {th }}$ March, $\mathrm{F}=108.69, p<0.05 ; 31^{\text {st }}$ March, $\mathrm{F}=15.47, p<0.05 ; 3^{\text {rd }}$ April, $\mathrm{F}=102.67, p<0.05 ; 7^{\text {th }}$ April, $\mathrm{F}=187.67, p<0.05 ;$ $10^{\text {th }}$ April, $\mathrm{F}=187.67, p<0.05 ; 17^{\text {th }}$ April, $\left.\mathrm{F}=174.89, p<0.05\right)$. df, degrees of freedom; Eth, ethephon; F, F-distribution; Mes, mesotrione; Pc, prohexadione calcium; PGRs, plant growth regulators; SE, standard error.

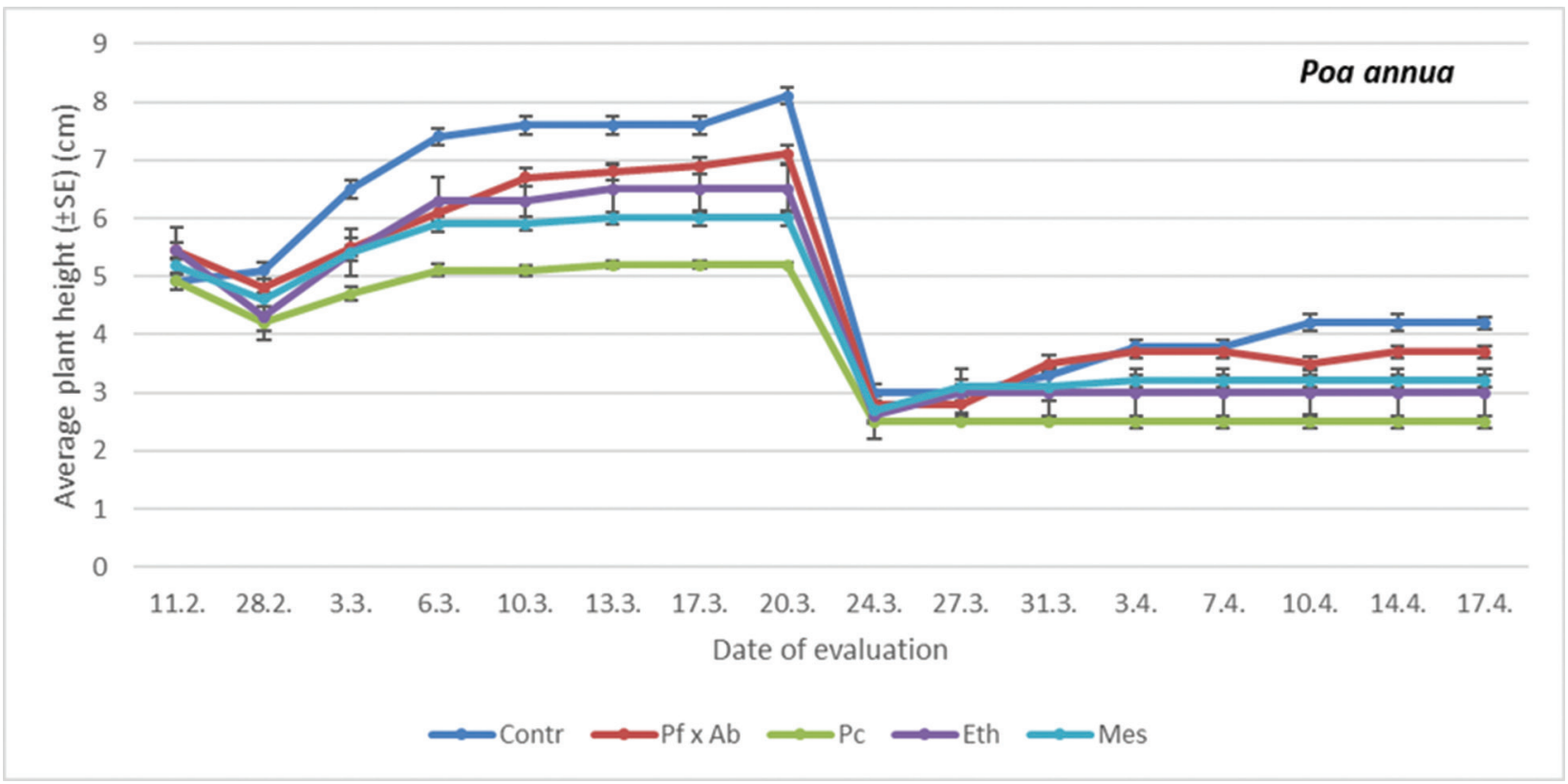

Figure 4. The average plant height on annual bluegrass treated with different PGRs. Within each evaluation date, a comparison was done between different treatments (PGRs; Student-Neuman Keuls at $p<0.05$ ). For comparisons within dates, $\mathrm{df}=4.24\left(11^{\text {th }}\right.$ February, $\mathrm{F}=0.62, p=0.6526 ; 28^{\text {th }}$ February, $\mathrm{F}=10.38, p<0.05 ; 3^{\text {rd }}$ March, $\mathrm{F}=12.97, p<0.05$; $6^{\text {th }}$ March, $\mathrm{F}=19.11, p<0.05 ; 10^{\text {th }}$ March, $\mathrm{F}=23.30, p<0.05 ; 13^{\text {th }}$ March, $\mathrm{F}=24.30, p<0.05 ; 17^{\text {th }}$ March, $\mathrm{F}=22.24$, $p<0.05 ; 20^{\text {th }}$ March, $\mathrm{F}=32.62, p<0.05 ; 24^{\text {th }}$ March, $\mathrm{F}=13.20, p=0.0624 ; 27^{\text {th }}$ March $, \mathrm{F}=20.20, p=0.0523$; $31^{\text {st }}$ March, $\mathrm{F}=30.30, p<0.05 ; 3^{\text {rd }}$ April, $\mathrm{F}=26.11, p<0.05 ; 7^{\text {th }}$ April, $\mathrm{F}=25.13, p<0.05 ; 10^{\text {th }}$ April, $\mathrm{F}=40.11$, $p<0.05 ; 14^{\text {th }}$ April, $\mathrm{F}=52.00, p<0.05 ; 17^{\text {th }}$ April, $\left.\mathrm{F}=142.37, p<0.05\right)$. df, degrees of freedom; Eth, ethephon; F, F-distribution; Mes, mesotrione; Pc, prohexadione calcium; PGRs, plant growth regulators; SE, standard error. 


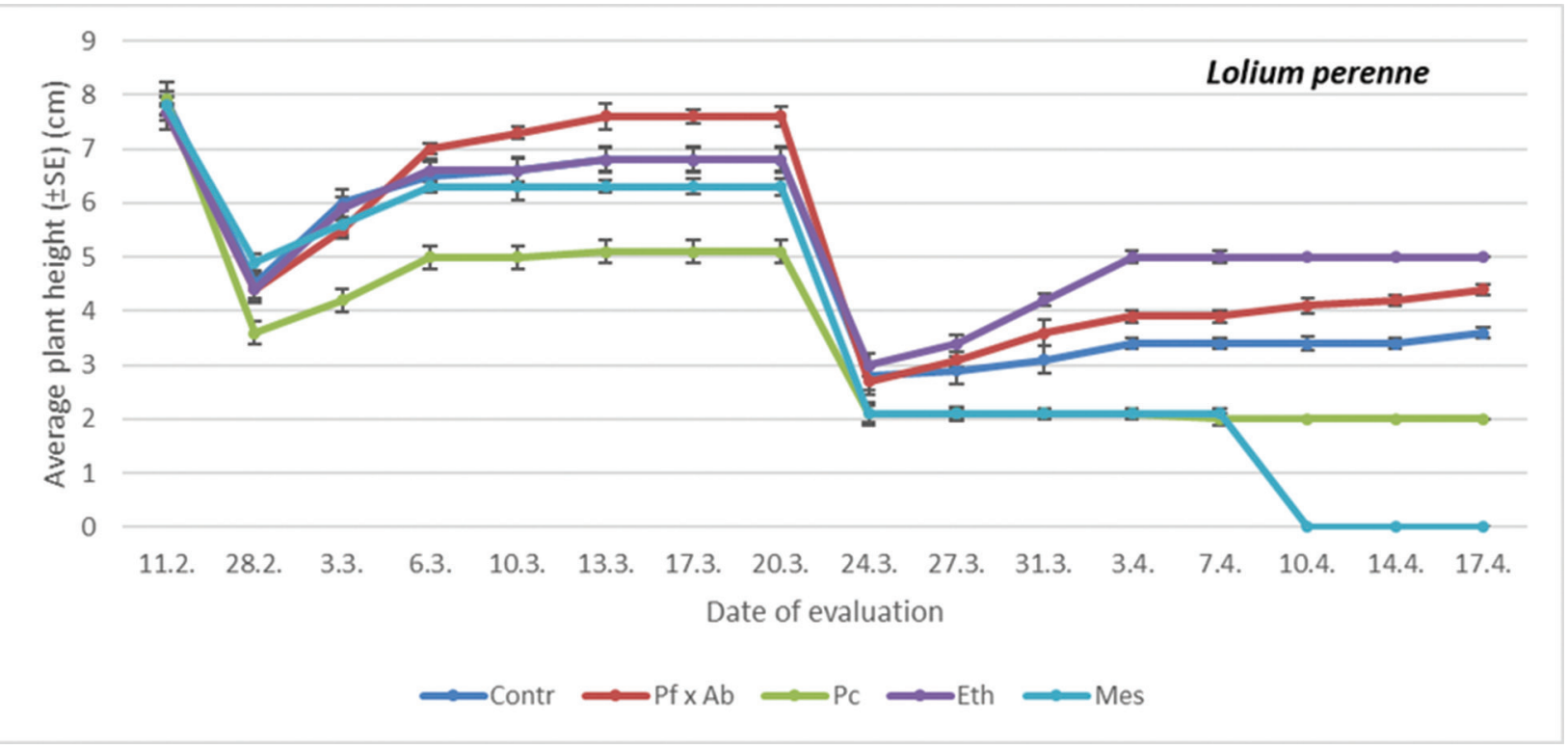

Figure 5. The average plant height on perennial ryegrass treated with different PGRs. Within each evaluation date, a comparison was done between different treatments (PGRs; Student-Neuman Keuls at $p<0.05$ ). For comparisons within dates, $\mathrm{df}=4.24\left(11^{\text {th }}\right.$ February, $\mathrm{F}=5.42, p=0.0726 ; 28^{\text {th }}$ February, $\mathrm{F}=13.13, p=0.0595 ; 3^{\text {rd }} \mathrm{March}, \mathrm{F}=44.97$, $p<0.05 ; 6^{\text {th }}$ March, $\mathrm{F}=39.81, p<0.05 ; 10^{\text {th }}$ March, $\mathrm{F}=11.30, p<0.05 ; 13^{\text {th }}$ March, $\mathrm{F}=16.30, p<0.05 ; 17^{\text {th }}$ March, $\mathrm{F}=33.24, p<0.05 ; 20^{\text {th }}$ March, $\mathrm{F}=32.62, p<0.05 ; 24^{\text {th }}$ March, $\mathrm{F}=23.11, p=0.0724 ; 27^{\text {th }}$ March, $\mathrm{F}=23.26, p=0.06$; $31^{\text {st }}$ March, $\mathrm{F}=11.30, p<0.05 ; 3^{\text {rd }}$ April, $\mathrm{F}=30.11, p<0.05 ; 7^{\text {th }}$ April, $\mathrm{F}=44.23, p<0.05 ; 10^{\text {th }}$ April, $\mathrm{F}=30.60$, $p<0.05 ; 14^{\text {th }}$ April, $\mathrm{F}=16.00, p<0.05 ; 17^{\text {th }}$ April, $\left.\mathrm{F}=88.37, p<0.05\right)$. df, degrees of freedom; Eth, ethephon; $\mathrm{F}$, F-distribution; Mes, mesotrione; Pc, prohexadione calcium; PGRs, plant growth regulators; SE, standard error.

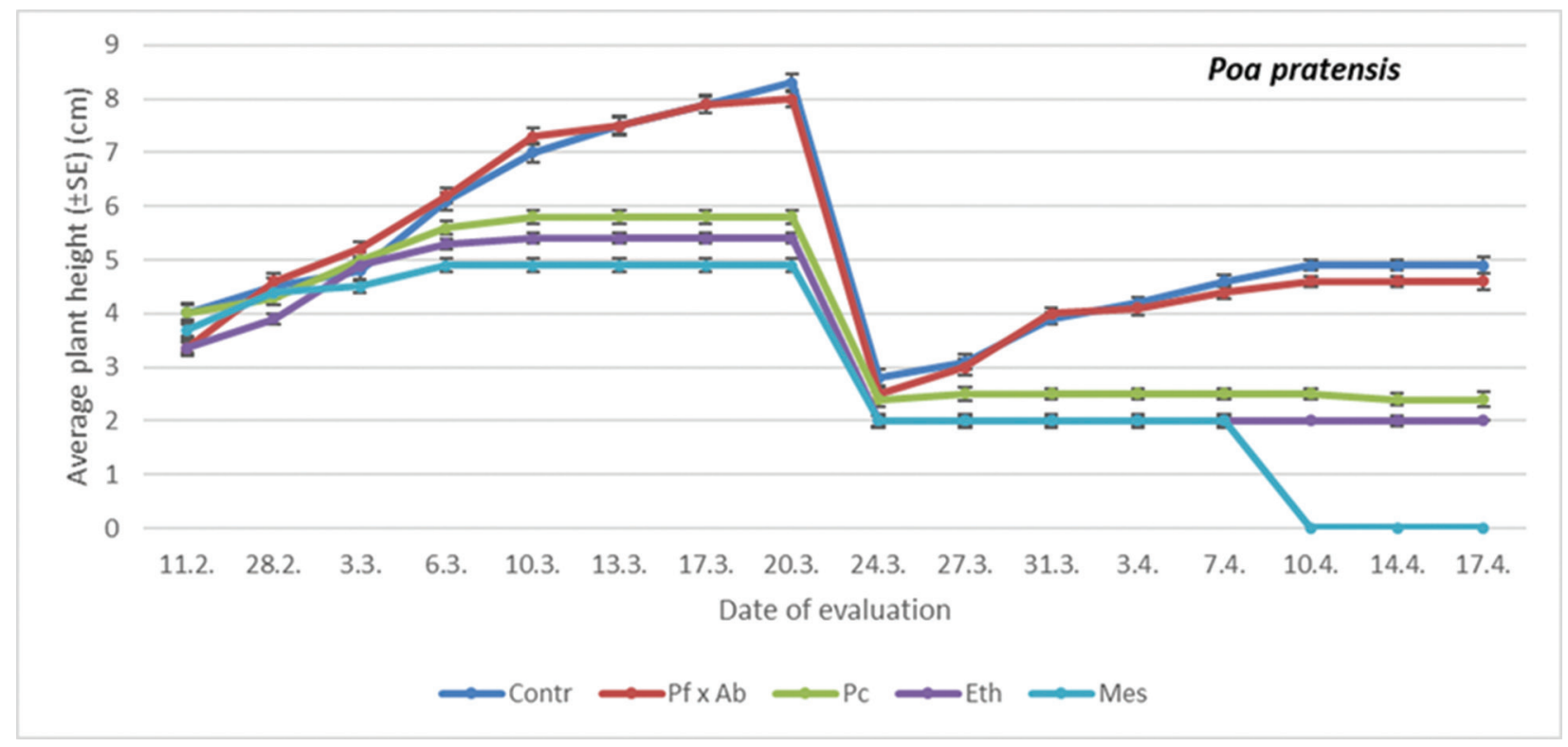

Figure 6. The average plant height on Kentucky bluegrass treated with different PGRs. Within each evaluation date, a comparison was done between different treatments (PGRs; Student-Neuman Keuls at $p<0.05$ ). For comparisons within dates, $\mathrm{df}=4.24\left(11^{\text {th }}\right.$ February, $\mathrm{F}=3.02, p=0.0626 ; 28^{\text {th }}$ February, $\mathrm{F}=11.26, p=0.0485 ; 3^{\text {rd }}$ March, $\mathrm{F}=11.97$, $p<0.05 ; 6^{\text {th }}$ March, $\mathrm{F}=103.81, p<0.05 ; 10^{\text {th }}$ March, $\mathrm{F}=151.20, p<0.05 ; 13^{\text {th }}$ March $, \mathrm{F}=23.30, p<0.05 ; 17^{\text {th }}$ March, $\mathrm{F}=55.24, p<0.05 ; 20^{\text {th }}$ March, $\mathrm{F}=32.62, p=0.0532 ; 24^{\text {th }}$ March, $\mathrm{F}=7.11, p=0.0814 ; 27^{\text {th }}$ March, $\mathrm{F}=23.26, p=0.08$; $31^{\text {st }}$ March, $\mathrm{F}=30.30, p<0.05 ; 3^{\text {rd }}$ April, $\mathrm{F}=25.11, p<0.05 ; 7^{\text {th }}$ April, $\mathrm{F}=38.23, p<0.05 ; 10^{\text {th }}$ April, $\mathrm{F}=30.60$, $p<0.05 ; 14^{\text {th }}$ April, $\mathrm{F}=32.00, p<0.05 ; 17^{\text {th }}$ April, $\left.\mathrm{F}=30.37, p<0.05\right)$. df, degrees of freedom; Eth, ethephon; $\mathrm{F}$, F-distribution; Mes, mesotrione; Pc, prohexadione calcium; PGRs, plant growth regulators; SE, standard error. 
Table 4. Repeated measures ANOVA parameters for the main effects and associated interaction for average tiller number.

\begin{tabular}{lrrr}
\hline Source between variables & df & F & $p$ \\
\hline All between & 28 & 88.1 & $<0.05$ \\
Intercept & 1 & 77.1 & $<0.05$ \\
Treatment & 4 & 109.8 & $<0.05$ \\
Turfgrass species & 2 & 145.2 & $<0.05$ \\
Experiment type & 1 & 11.6 & $<0.05$ \\
Treatment $\times$ turfgrass species & 8 & 14.7 & $<0.05$ \\
Turfgrass species $\times$ experiment type & 4 & 4.7 & $<0.05$ \\
Treatment $\times$ turfgrass species $\times$ experiment type & 8 & 12.3 & $<0.05$ \\
\hline Source within Experiment 1 & & & \\
\hline Within interactions & 126 & 87.3 & $<0.05$ \\
Date of evaluation & 18 & 40.9 & $<0.05$ \\
Date of evaluation $\times$ treatment & 72 & 4.9 & $<0.05$ \\
Date of evaluation $\times$ turfgrass species & 36 & 3.4 & $<0.05$ \\
\hline Source within Experiment 2 & & & $<5$ \\
\hline Within interactions & 98 & 65.1 & $<0.05$ \\
Date of evaluation & 14 & 55.3 & $<0.05$ \\
Date of evaluation $\times$ treatment & 56 & 44.4 & $<0.05$ \\
Date of evaluation $\times$ turfgrass species & 28 & 25.1 & $<0.05$ \\
\hline
\end{tabular}

df - degrees of freedom; F - F-distribution is a continuous probability distribution that arises frequently as the null distribution of test statistics; $p-p$-value as probability of obtaining test results at least as extreme as the results observed under the assumption that the null hypothesis is correct.

ANOVA, analysis of variance.

\section{Impact of experiment type on the average number of tillers per plant of turfgrass species}

We have detected a statistically significant impact of all main factors and their interactions on the average number of tillers per plant in Experiments 1 and 2. All values are presented in Table 4 based on the general analysis in Experiment 1, the average number of tillers per plant was significantly the highest in the Pc treatment $(4.40 \pm 0.09)$. Significantly, the lowest average number of tillers was detected in the Mes treatment $(3.00 \pm 0.05)$, which is $>1$ tiller per plant lower than on turfgrass treated with Pc. Significantly, the lowest average number of tillers per plant in Experiment 2 was recorded in the Mes treatment $(3.31 \pm 0.07)$, while the highest average number of tillers per plant was detected in the Eth treatment $(4.32 \pm 0.10)$ and in the Pc treatment $(4.20 \pm 0.08)$. Therefore, the average tiller number on plants in positive control reached $>1$ tiller per plant less, than plants exposed to Eth and Pc.

\section{The average number of tillers per plant of turfgrass species in Experiment 1}

All main effects and their interactions, which have influenced the average number of tillers in Experiment 1, are presented in Table 5. In general, the highest average number of tillers was detected on turfgrass, which was treated with Pc. Significantly the lowest number of tillers per plant was detected at Mes treatment $(3.06 \pm 0.05)$. In general, the highest number of tillers per grass was recorded, when grass was sprayed with Pc $(4.40 \pm 0.09)$. When annual bluegrass was sprayed with the product Eth, $3.45 \pm 0.12$ tillers per plant were detected, while $4.06 \pm 0.12$ tillers per plant were detected when annual bluegrass was sprayed with Pc. On the other hand, when perennial ryegrass was treated with Eth, $4.41 \pm 0.18$ tillers per plant were detected, while $4.47 \pm 0.14$ tillers per plant were detected when the Pc was used. Eth and Pc, as active substances, reached the same effect.

When sprayed with Pc, the average number of tillers at annual bluegrass was ranging from $3.20 \pm 0.16$ on $28^{\text {th }}$ February, $5.6 \pm 0.10$ on $27^{\text {th }}$ February to $4.80 \pm 0.15$ on $3^{\text {rd }}$ April. At Mes treatment after first mowing, the average number of tillers reached 3.6, meanwhile 3 days after last mowing 3 tillers were on average recorded at annual bluegrass. Additional values are presented in Figure 7.

The average number of tillers per perennial ryegrass was the highest in treatments, where we have used Eth and Pc. What's more, on several dates of evaluation

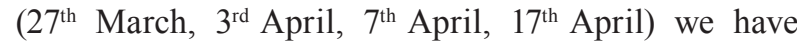
detected on average 6 tillers per plant. At Mes treatment, the stagnation in tiller formation was detected 14 days before the second mowing. Detailed values are presented in Figure 8.

Where Kentucky bluegrass was sprayed with Pc, the highest average number of tillers was measured in almost all evaluation dates. Almost 6 tillers per plant were measured on the day of the second mowing. All additional values are presented in Figure 9. 
Table 5. Repeated measures ANOVA parameters for the main effects and associated interactions for average tiller number per plant within turfgrass species in Experiments 1 and 2 (error $\mathrm{df}=474$ ).

\begin{tabular}{|c|c|c|c|c|}
\hline Experiment type & Source & $\mathrm{df}$ & $\mathrm{F}$ & $p$ \\
\hline \multirow[t]{12}{*}{1} & Sources within annual bluegrass & & & \\
\hline & Date of evaluation & 18 & 11.7 & $<0.05$ \\
\hline & Treatment & 4 & 43.3 & $<0.05$ \\
\hline & Date of evaluation $\times$ treatment & 72 & 2.9 & $<0.05$ \\
\hline & Source within perennial ryegrass & & & \\
\hline & Date of evaluation & 18 & 19.9 & $<0.05$ \\
\hline & Treatment & 4 & 50.7 & $<0.05$ \\
\hline & Date of evaluation $\times$ treatment & 72 & 2.7 & $<0.05$ \\
\hline & Source within Kentucky bluegrass & & & \\
\hline & Date of evaluation & 18 & 13.3 & $<0.05$ \\
\hline & Treatment & 4 & 44.4 & $<0.05$ \\
\hline & Date of evaluation $\times$ treatment & 72 & 13.3 & $<0.05$ \\
\hline \multirow[t]{12}{*}{2} & Sources within annual bluegrass & & & \\
\hline & Date of evaluation & 14 & 4.4 & $<0.05$ \\
\hline & Treatment & 4 & 24.8 & $<0.05$ \\
\hline & Date of evaluation $\times$ treatment & 56 & 3.8 & $<0.05$ \\
\hline & Source within perennial ryegrass & & & \\
\hline & Date of evaluation & 14 & 4.7 & $<0.05$ \\
\hline & Treatment & 4 & 25.6 & $<0.05$ \\
\hline & Date of evaluation $\times$ treatment & 56 & 2.7 & $<0.05$ \\
\hline & Source within Kentucky bluegrass & & & \\
\hline & Date of evaluation & 18 & 3.0 & $<0.05$ \\
\hline & Treatment & 4 & 22 & $<0.05$ \\
\hline & Date of evaluation $\times$ treatment & 72 & 13.33 & $<0.05$ \\
\hline
\end{tabular}

df - degrees of freedom; F - F-distribution is a continuous probability distribution that arises frequently as the null distribution of test statistics; $p-p$-value as probability of obtaining test results at least as extreme as the results observed under the assumption that the null hypothesis is correct. ANOVA, analysis of variance.

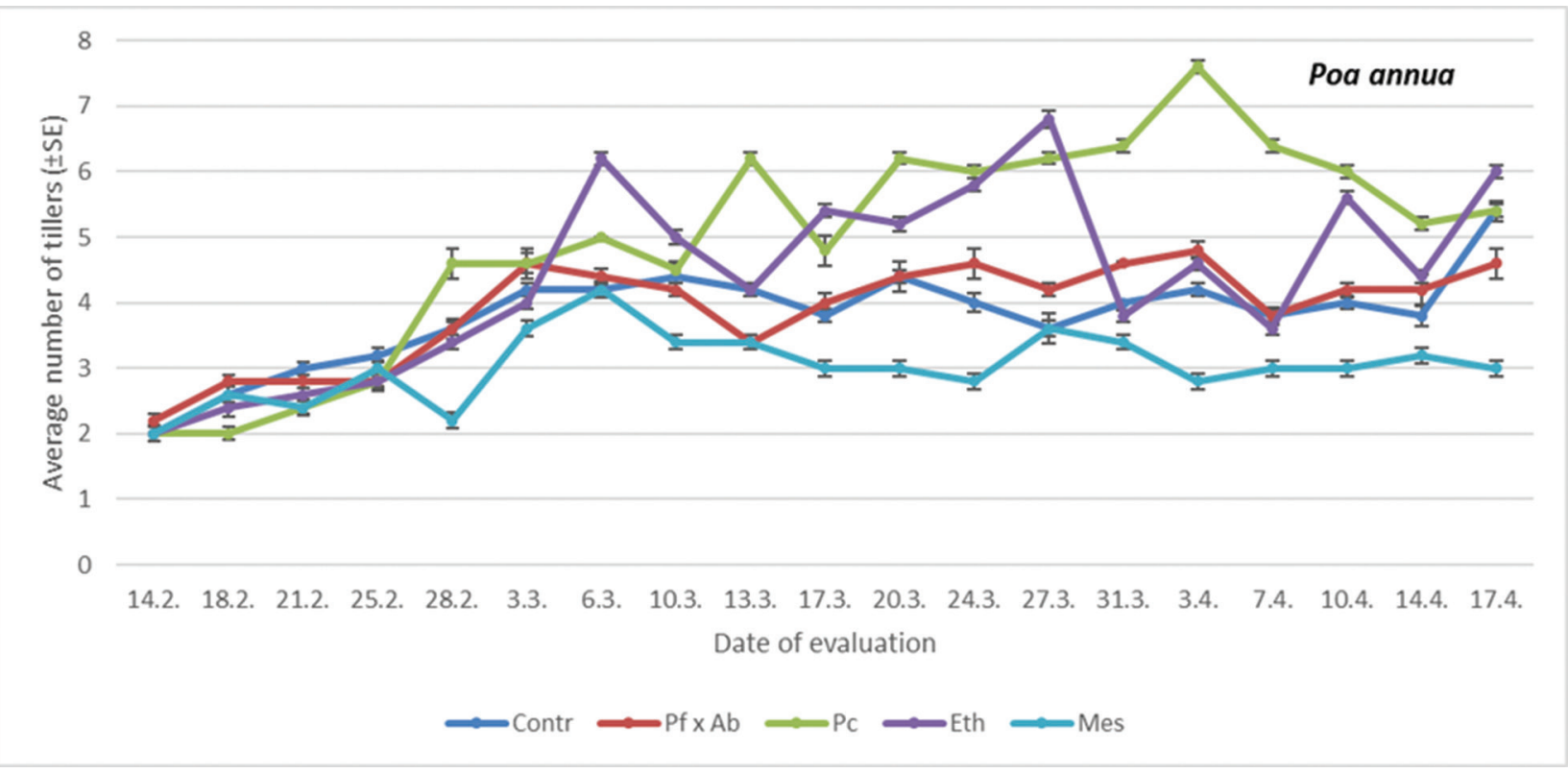

Figure 7. The average number of tillers on annual bluegrass treated with different PGRs. Within each evaluation date, a comparison was done between different treatments (PGRs; Student-Neuman Keuls at $p<0.05$ ). For comparisons within dates, $\mathrm{df}=4.24\left(14^{\text {th }}\right.$ February, $\mathrm{F}=3.02, p=0.0626 ; 18^{\text {th }}$ February, $\mathrm{F}=0.57, p=0.0485 ; 21^{\text {st }}$ February, $\mathrm{F}=0.50$, $p=0.7360 ; 25^{\text {th }}$ February, $\mathrm{F}=3.30, p=0.0623 ; 28^{\text {th }}$ February, $\mathrm{F}=30.40, p<0.05 ; 3^{\text {rd }}$ March, $\mathrm{F}=0.88, p<0.05$; $6^{\text {th }}$ March, $\mathrm{F}=4.56, p<0.05 ; 10^{\text {th }}$ March, $\mathrm{F}=4.23, p<0.05 ; 13^{\text {th }}$ March, $\mathrm{F}=6.87, p<0.05 ; 17^{\text {th }}$ March, $\mathrm{F}=5.63$, $p<0.05 ; 20^{\text {th }}$ March, $\mathrm{F}=5.63, p<0.05 ; 24^{\text {th }}$ March, $\mathrm{F}=6.19, p<0.05 ; 27^{\text {th }}$ March, $\mathrm{F}=23.62 p<0.05 ; 31^{\text {st }}$ March, $\mathrm{F}=2.71, p<0.0591 ; 3^{\text {rd }}$ April, $\mathrm{F}=20.11, p<0.05 ; 7^{\text {th }}$ April, $\mathrm{F}=7.25, p<0.05 ; 10^{\text {th }}$ April, $\mathrm{F}=81.15, p<0.05 ; 17^{\text {th }}$ April, $\mathrm{F}=30.11, p<0.05)$. df, degrees of freedom; Eth, ethephon; F, F-distribution; Mes, mesotrione; Pc, prohexadione calcium; PGRs, plant growth regulators; SE, standard error. 


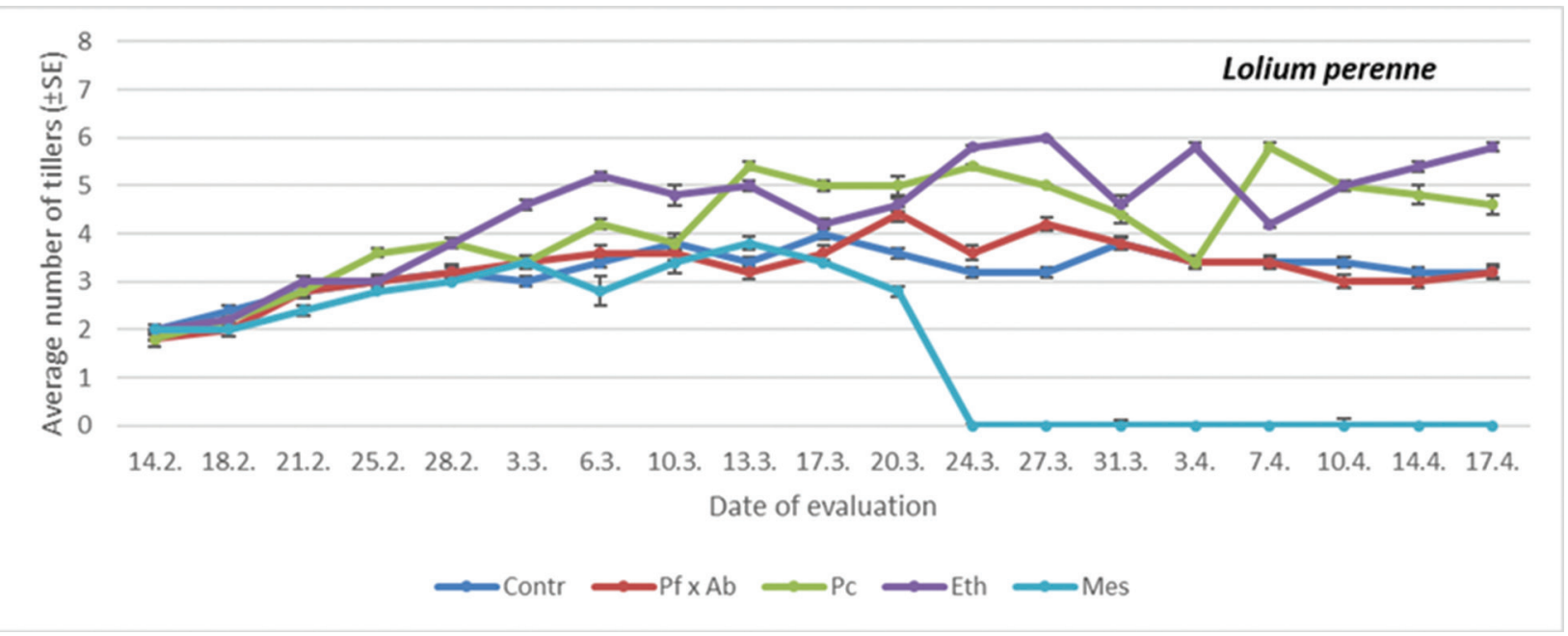

Figure 8. The average number of tillers on perennial ryegrass treated with different PGRs. Within each evaluation date, a comparison was done between different treatments (PGRs; Student-Neuman Keuls at $p<0.05$ ). For comparions within date, $\mathrm{df}=4.24\left(14^{\text {th }}\right.$ February, $\mathrm{F}=0.0723, p<0.05 ; 18^{\text {th }}$ February, $\mathrm{F}=2.09, p=0.1200$; $21^{\text {st }}$ February, $\mathrm{F}=1.55, p=0.2274 ; 25^{\text {th }}$ February, $\mathrm{F}=12.12, p=0.2236 ; 28^{\text {th }}$ February, $\mathrm{F}=13.07, P<0.05$; $3^{\text {rd }}$ March, $\mathrm{F}=1.10, p<0.05 ; 6^{\text {th }}$ March, $\mathrm{F}=7.50, p<0.05 ; 10^{\text {th }}$ March, $\mathrm{F}=10.10, p=0.0564 ; 13^{\text {th }} \mathrm{March}^{\mathrm{r}}$, $\mathrm{F}=19.29, p<0.05 ; 17^{\text {th }}$ March $, \mathrm{F}=3.21, p=0.0345 ; 20^{\text {th }}$ March, $\mathrm{F}=6.31, p<0.05 ; 24^{\text {th }}$ March, $\mathrm{F}=4.75, p<0.05$; $27^{\text {th }}$ March, $\mathrm{F}=30.30, p<0.05 ; 31^{\text {st }}$ March, $\mathrm{F}=21.70, p<0.05 ; 3^{\text {rd }}$ April, $\mathrm{F}=15.08, p<0.05 ; 7^{\text {th }}$ April, $\mathrm{F}=25.40$, $p<0.05 ; 10^{\text {th }}$ April, $\mathrm{F}=61.13, p<0.05 ; 14^{\text {th }}$ April, $\mathrm{F}=61.13, p<0.05 ; 17^{\text {th }}$ April, $\left.\mathrm{F}=33.15 ; p<0.05\right)$. df, degrees of freedom; Eth, ethephon; F, F-distribution; Mes, mesotrione; Pc, prohexadione calcium; PGRs, plant growth regulators; SE, standard error.

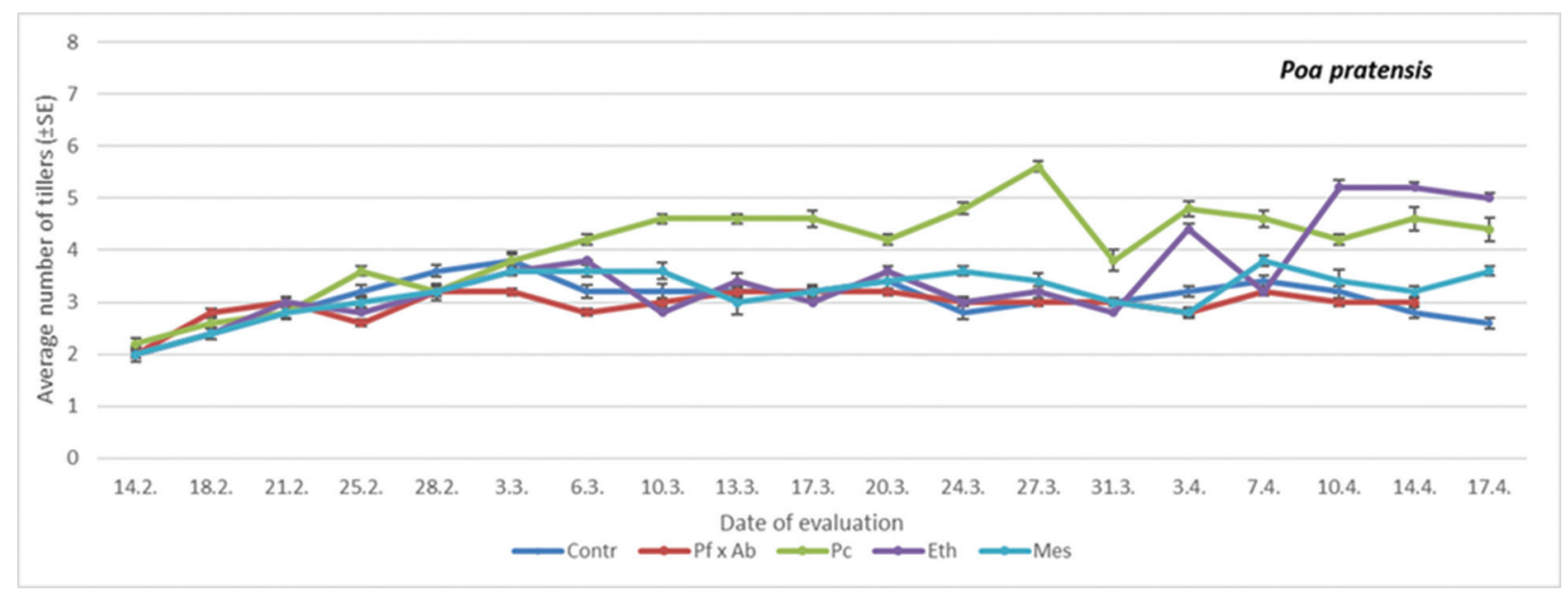

Figure 9. The average number of tillers on Kentucky bluegrass treated with different PGRs. Within each evaluation date, a comparison was done between different treatments (PGRs; Student-Neuman Keuls at $p<0.05$ ). For comparisons within date, $\mathrm{df}=4.24\left(14^{\text {th }}\right.$ February, $\mathrm{F}=3.09, p<0.05 ; 18^{\text {th }}$ February, $\mathrm{F}=2.09, p=0.7200 ; 21^{\text {st }}$ February, $\mathrm{F}=1.55$, $p=0.2274 ; 25^{\text {th }}$ February, $\mathrm{F}=30.12, p=0.7236 ; 28^{\text {th }}$ February, $\mathrm{F}=20.07, p<0.05 ; 3^{\text {rd }}$ March, $\mathrm{F}=1.10, p<0.05$; $6^{\text {th }}$ March, $\mathrm{F}=7.50, p<0.05 ; 10^{\text {th }}$ March, $\mathrm{F}=10.10, p=0.0564 ; 13^{\text {th }}$ March, $\mathrm{F}=19.29, p<0.05 ; 17^{\text {th }}$ March, $\mathrm{F}=3.21$, $p=0.0345 ; 20^{\text {th }}$ March, $\mathrm{F}=6.31, p<0.05 ; 24^{\text {th }}$ March, $\mathrm{F}=4.75, p<0.05 ; 27^{\text {th }}$ March, $\mathrm{F}=30.30, p<0.05 ; 31^{\text {st }}$ March, $\mathrm{F}=21.70, p<0.05 ; 3^{\text {rd }}$ April, $\mathrm{F}=15.08, p<0.05 ; 7^{\text {th }}$ April, $\mathrm{F}=75.40, p=0.0935 ; 10^{\text {th }}$ April, $\mathrm{F}=61.13, p<0.05$; $14^{\text {th }}$ April, $\mathrm{F}=77.13, p<0.05 ; 17^{\text {th }}$ April, $\left.\mathrm{F}=37.15 ; p<0.05\right)$. df, degrees of freedom; Eth, ethephon; F, F-distribution; Mes, mesotrione; Pc, prohexadione calcium; PGRs, plant growth regulators; SE, standard error.

\section{The average number of tillers per plant of turfgrass species in Experiment 2}

All main effects and their interactions, which have influenced the average number of tillers per plant on specific turfgrass, are presented in Table 5. In general, the average number of tillers ranged from $3.48 \pm 0.04$ for Mes, $4.32 \pm 0.09$ for Eth, $3.65 \pm 0.05$ for the Control, $4.20 \pm 0.08$ for Pc, and $3.55 \pm 0.05$ tillers per plant for Pf $\times A b$. When annual bluegrass was treated with Eth, $3.27 \pm 0.07$ tillers per plant were detected; in contrast, 
$5.20 \pm 0.18$ tillers per plant were detected for perennial ryegrass. When Kentucky bluegrass was sprayed with Pc, $3.88 \pm 0.09$ tillers per plant were detected. Additional data are presented in Figures 10-12.

When annual bluegrass was sprayed in Experiment 2, spraying with Pc proved the highest average number of tillers per grass, reaching almost 5 tillers per plant on $3^{\text {rd }}$ and $7^{\text {th }}$ June. Additional values are described in Figure 10.

When perennial ryegrass was sprayed either with Pc or Mes, the highest tiller number was detected in almost all dates of evaluation throughout the entire evaluation period. When perennial ryegrass was sprayed with Mes, the average tiller number per plant was the lowest in

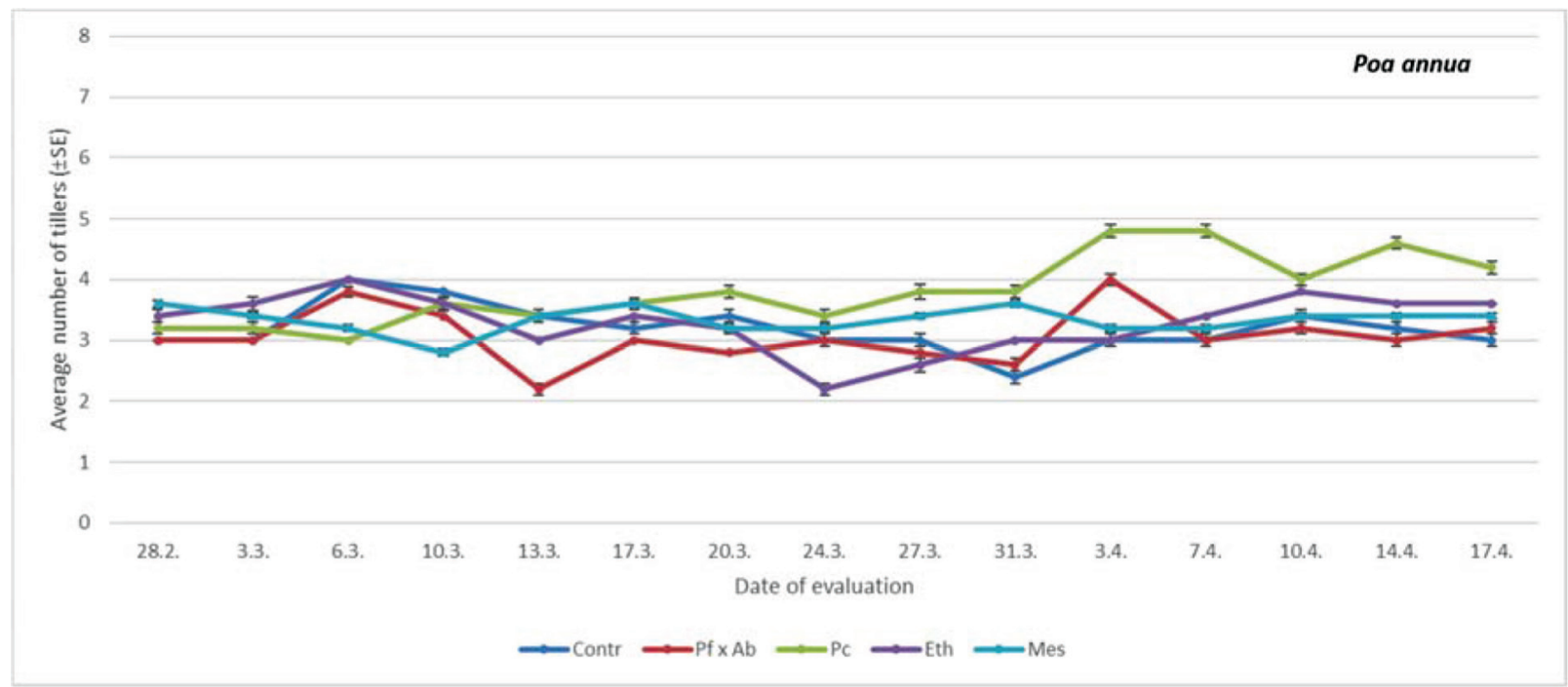

Figure 10. The average number of tillers on annual bluegrass treated with different PGRs. Within each evaluation date, comparison was done between different treatment (PGRs; Student-Neuman Keuls at $p<0.05$ ). For comparisons within dates, $\mathrm{df}=4.24\left(28^{\text {th }}\right.$ February, $\mathrm{F}=9.06, p=0.0936 ; 3^{\text {rd }}$ March, $\mathrm{F}=7.38, p<0.05 ; 6^{\text {th }}$ March, $\mathrm{F}=4.56, p<0.05$; $10^{\text {th }}$ March, $\mathrm{F}=4.23, p<0.05 ; 13^{\text {th }}$ March, $\mathrm{F}=13.87, p<0.05 ; 17^{\text {th }}$ March, $\mathrm{F}=77.33, p<0.05 ; 20^{\text {th }}$ March, $\mathrm{F}=130.63$, $p<0.05 ; 24^{\text {th }}$ March, $\mathrm{F}=31.19, p<0.05 ; 27^{\text {th }}$ March, $\mathrm{F}=66.62 p<0.05 ; 31^{\text {st }}$ March, $\mathrm{F}=77.71, p<0.05 ; 3^{\text {rd }}$ April, $\mathrm{F}=220.11, p<0.05 ; 7^{\text {th }}$ April, $\mathrm{F}=34.25, p<0.05 ; 10^{\text {th }}$ April, $\mathrm{F}=111.15, p<0.05 ; 17^{\text {th }}$ April, $\left.\mathrm{F}=230.11, p<0.05\right)$. df, degrees of freedom; Eth, ethephon; F, F-distribution; Mes, mesotrione; Pc, prohexadione calcium; PGRs, plant growth regulators; SE, standard error.

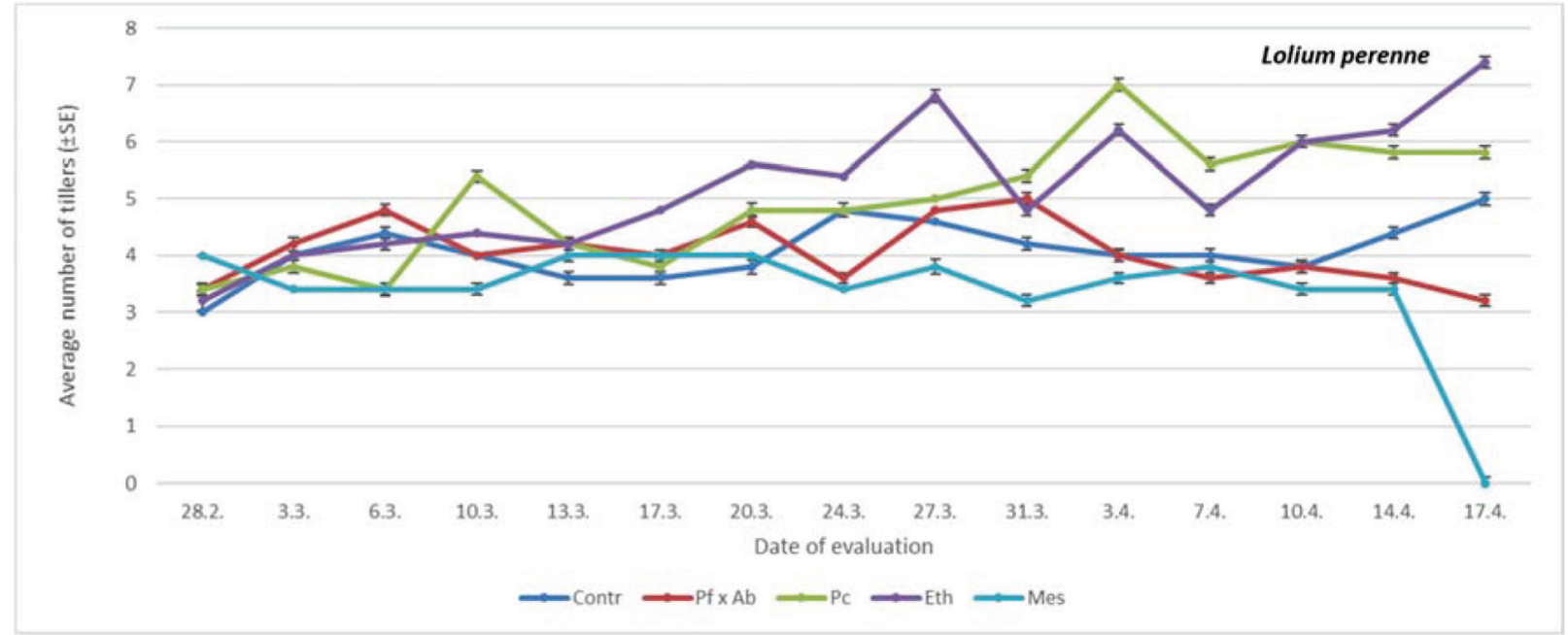

Figure 11. The average number of tiller on perennial ryegrass treated with different PGRs. Within each evaluation date, comparison was done between different treatments (PGRs; Student-Neuman Keuls at $p<0.05$ ). For comparions within date, $\mathrm{df}=4.24\left(28^{\text {th }}\right.$ February, $\mathrm{F}=17.06, p=0.0936 ; 3^{\text {rd }}$ March, $\mathrm{F}=7.38, p=0.2005 ; 6^{\text {th }}$ March, $\mathrm{F}=4.56$, $p<0.05 ; 10^{\text {th }}$ March, $\mathrm{F}=4.23, p<0.05 ; 13^{\text {th }}$ March, $\mathrm{F}=22.87, p<0.05 ; 17^{\text {th }}$ March, $\mathrm{F}=77.33, p<0.05 ; 20^{\text {th }}$ March, $\mathrm{F}=130.63, p<0.05 ; 24^{\text {th }}$ March, $\mathrm{F}=70.16, p<0.05 ; 27^{\text {th }}$ March, $\mathrm{F}=30.11, p<0.05 ; 31^{\text {st }}$ March, $\mathrm{F}=13.71, p<0.05 ; 3^{\text {rd }}$ April, $\mathrm{F}=70.11, p<0.05 ; 7^{\text {th }}$ April, $\mathrm{F}=130.35, p<0.05 ; 10^{\text {th }}$ April, $\mathrm{F}=17.15, p<0.05 ; 17^{\text {th }}$ April, $\left.\mathrm{F}=90.11, p<0.05\right)$. df, degrees of freedom; Eth, ethephon; F, F-distribution; Mes, mesotrione; Pc, prohexadione calcium; PGRs, plant growth regulators; SE, standard error. 


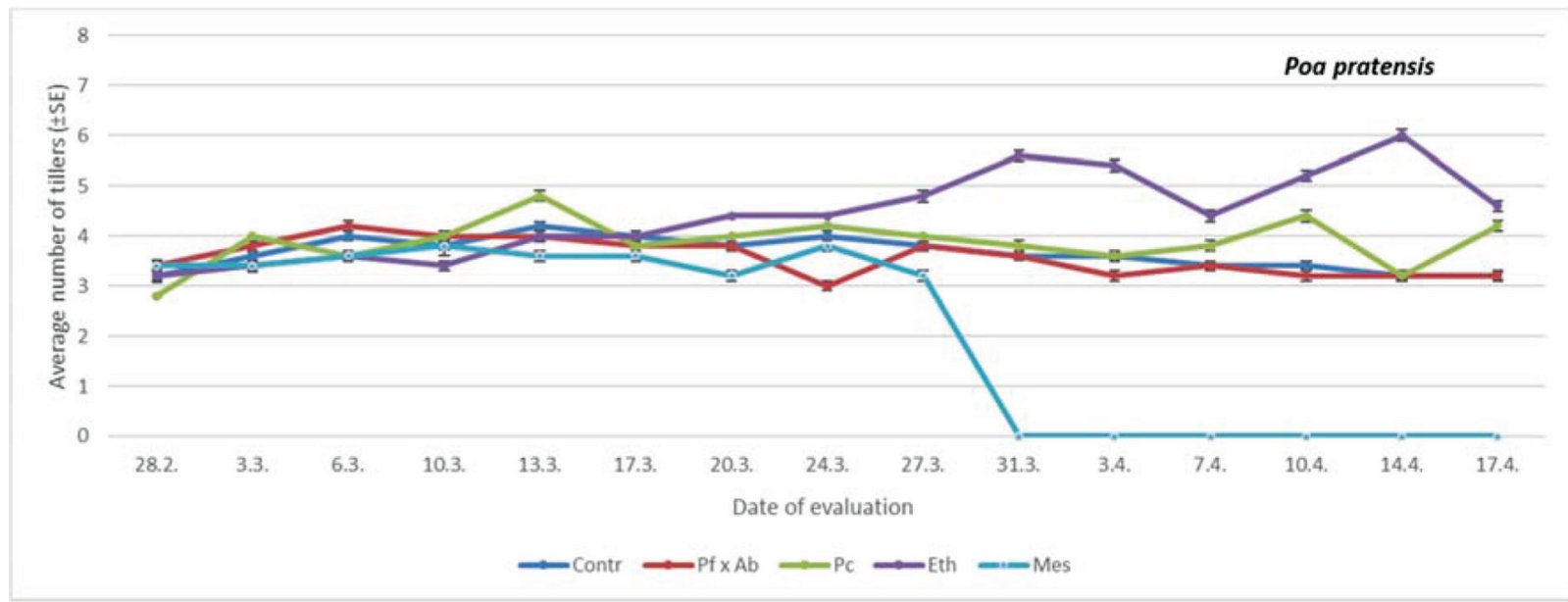

Figure 12. The average number of tillers per plant on Kentucky bluegrass treated with different PGRs. Within each evaluation date, comparison was done between different treatments (PGRs; Student-Neuman Keuls at $p<0.05$ ). For comparions within date, $\mathrm{df}=4.24\left(28^{\text {th }}\right.$ February, $\mathrm{F}=7.03, p=0.0636 ; 3^{\text {rd }}$ March, $\mathrm{F}=9.33, p=0.4005$; $6^{\text {th }}$ March, $\mathrm{F}=9.53, p=0.5246 ; 10^{\text {th }}$ March, $\mathrm{F}=9.23, p<0.05 ; 13^{\text {th }}$ March, $\mathrm{F}=22.87, p=0.0563 ; 17^{\text {th }}$ March, $\mathrm{F}=7.23, p=0.0625 ; 20^{\text {th }}$ March, $\mathrm{F}=30.11, p<0.05 ; 24^{\text {th }}$ March, $\mathrm{F}=70.16, p<0.05 ; 27^{\text {th }}$ March, $\mathrm{F}=11.11, p<0.05$; $31^{\text {st }}$ March, $\mathrm{F}=143.61, p<0.05 ; 3^{\text {rd }}$ April, $\mathrm{F}=270.11, p<0.05 ; 7^{\text {th }}$ April, $\mathrm{F}=136.31, p<0.05 ; 10^{\text {th }}$ April, $\mathrm{F}=141.15$, $p<0.05 ; 17^{\text {th }}$ April, $\left.\mathrm{F}=90.11, p<0.05\right)$. df, degrees of freedom; Eth, ethephon; F, F-distribution; Mes, mesotrione; Pc, prohexadione calcium; PGRs, plant growth regulators; SE, standard error.

almost all dates. All detailed numbers are presented in Figure 11.

After second mowing, when Kentucky bluegrass was sprayed either with Eth or Mes, the average number of tillers per plant was either the highest or the lowest. Detailed data are presented in Figure 12.

\section{Plant height ratio between two dates of evaluation (Experiment 1)}

Table 6 presents the plant height ratio of three turfgrass species across five treatments over three growth periods. Regarding the first two periods of growth, Pc most efficiently restrained the growth of annual bluegrass, as the average plant height increased by only $28 \%$ in the first period, while in the second period, the annual bluegrass did not grow at all after mowing. Pc also showed a restraining effect on the growth of perennial ryegrass and Kentucky bluegrass in the first period, in which the plants were $6 \%$ shorter before the first mowing or only $9 \%$ taller than at the first measurement, respectively. Pc also showed a restraining effect on the latter two turfgrass species in the second period, and 3 weeks after mowing, the plants grew to only $20 \%$ of their original height, but Eth also showed a significant inhibitory effect on both species.

However, interestingly, Eth did not show an effect on annual bluegrass. The herbicide Mes did not have any effect on annual bluegrass in the first two periods, but it affected the complete cessation of the growth of perennial ryegrass in the first period. The perennial ryegrass sprayed twice with this herbicide collapsed in the third growth period, while similarly treated Kentucky bluegrass collapsed in the second period.

\section{Tillers ratios between two dates of evaluation (Experiment 1)}

When we compared the number of tillers per plant of annual bluegrass in the first evaluation period, the ratio was the highest for the control treatment and the lowest for the $P f \times A b$ treatment. In the second evaluation period, the tiller number ratio was the lowest for plants sprayed with Eth. The most uniform decline in the tiller number ratio overall assessment periods was observed for $P f \times A b$ and Pc, with the largest decrease in the number of tillers found for $P f \times A b$. All detailed values are presented in Table 7.

\section{Plant height ratio between two dates of evaluation (Experiment 2)}

In Experiment 2, in the first and second assessment periods, the lowest growth ratio for annual bluegrass was found for the Pc treatment. This product also showed an inhibitory effect on the growth of the other two turfgrass species. The Mes treatment (herbicide) showed better performance, since, in the second period of growth, it caused the collapse of both turfgrass species. The remaining values are presented in Table 8.

\section{Tillers ratio indices between two dates of evaluation (Experiment 2)}

Tillers ratio measured on $20^{\text {th }}$ March for annual bluegrass plants sprayed with $P_{c} \times A b$ was $7 \%$ lower than the tillers ratio on $28^{\text {th }}$ February. Additionally, in the second period, the tillers ratio under this treatment increased only slightly $(6 \%)$. In both periods, comparable indices were found for the $P c \times A b$ and Mes treatments. After comparing the two evaluation dates in the second 
Table 6. Plant height ratio of three turfgrass species across five treatments and three growth periods - Experiment 1 .

\begin{tabular}{llccc}
\hline Turfgrass species & Treatment & \multicolumn{3}{c}{ Period } \\
\cline { 3 - 5 } & & $3^{\text {rd }}$ Mar $/ 11^{\text {th }} \mathrm{Feb}$ & $27^{\text {th }}$ Mar $/ 6^{\text {th }} \mathrm{Mar}$ & $17^{\text {th }} \mathrm{Apr} / 31^{\text {st }} \mathrm{Mar}$ \\
\hline Annual bluegrass & Contr & 2.03 & 1.45 & 1.10 \\
& $P f \times A b$ & 1.86 & 1.58 & 1.00 \\
& Pc & 1.28 & 1.00 & 1.00 \\
& Eth & 1.58 & 1.52 & 1.00 \\
& Mes & 1.81 & 1.52 & 1.00 \\
\hline Perennial ryegrass & Contr & 1.25 & 1.58 & 1.07 \\
& Pf $\times$ Ab & 1.17 & 1.71 & 1.00 \\
& Pc & 0.94 & 1.20 & 1.14 \\
& Eth & 1.05 & 1.17 & - \\
\hline Kentucky bluegrass & Contr & 1.00 & 1.00 & 1.35 \\
& Pf $\times$ Ab & 2.06 & 1.80 & 1.37 \\
& Pc & 2.41 & 1.57 & 1.00 \\
& Eth & 1.09 & 1.21 & 1.00 \\
\hline
\end{tabular}

$(-)$ because of the high efficacy of the product, we could not calculate the ratio; Feb - February; Mar - March; Apr - April.

Eth, ethephon; Mes, mesotrione; Pc, prohexadione calcium.

Table 8. Plant height ratio of three turfgrass species across five treatments and two growth periods - Experiment 2.

\begin{tabular}{llcc}
\hline Turfgrass species & Treatment & \multicolumn{2}{c}{ Period } \\
\cline { 3 - 4 } & & $20^{\text {th }}$ Mar $/ 28^{\text {th }} \mathrm{Feb}$ & $17^{\text {th }} \mathrm{Apr} / 23^{\text {rd }} \mathrm{Mar}$ \\
\hline Annual bluegrass & Contr & 1.62 & 1.40 \\
& $P c \times A b$ & 1.48 & 1.32 \\
& Pc & 1.24 & 1.00 \\
& Eth & 1.52 & 1.15 \\
Mes & 1.30 & 1.18 \\
Contr & $P c \times A b$ & 1.52 & 1.28 \\
& Pc & 1.73 & 0.95 \\
& Eth & 1.42 & 1.68 \\
Mes & Contr & 1.54 & - \\
& $P c \times A b$ & 1.28 & 1.75 \\
& Pc & 1.84 & 1.84 \\
& Eth & 1.74 & 1.02 \\
& Mes & 1.35 & 1.00 \\
\hline
\end{tabular}

(-) because of the high efficacy of the product, we could not calculate the ratio; Feb - February; Mar - March; Apr - April.

Eth, ethephon; Mes, mesotrione; Pc, prohexadione calcium.

evaluation period for annual bluegrass sprayed with Eth, the tillers ratio increased by $63 \% . P c \times A b$ also showed satisfactory performance on the development of a small number of tillers for annual bluegrass in the first period. The remaining details are presented in Table 9.

\section{DISCUSSION}

In a study under controlled conditions (greenhouse), we examined the activity of three growth regulators and a systemic herbicide on the height and development of three turfgrass species that most commonly occur in grass mixtures on football pitches (Brede and Duich, 1986). Perennial ryegrass and Kentucky bluegrass are important components of grass mixtures because they have a rapid recovery and high traffic tolerance, and annual bluegrass is one of the most important and most undesirable weeds on football pitches (Reicher et al., 2011; Park et al., 2019; Brosnan et al., 2020). The main goal of the research was to determine which preparation was the most effective for the control of annual bluegrass while having the least pronounced effects on perennial ryegrass and Kentucky bluegrass. In Experiment 1, we focussed on the effect of the studied products on grasses that had not been previously mowed, and in Experiment 2, we began to apply the tested products to annual bluegrass, perennial ryegrass and Kentucky bluegrass only after the first mowing. In all three turfgrass species, we wanted to study the response of uncut and once mowed grasses to the tested products, as the time 
Table 9. Tillers ratio of three turfgrass species across five treatments and two growth periods - Experiment 2.

\begin{tabular}{|c|c|c|c|}
\hline \multirow[t]{2}{*}{ Turfgrass species } & \multirow[t]{2}{*}{ Treatment } & \multicolumn{2}{|c|}{ Period } \\
\hline & & $20^{\text {th }} \mathrm{Mar} / 28^{\text {th }} \mathrm{Feb}$ & $17^{\text {th }} \mathrm{Apr} / 23^{\text {rd }} \mathrm{Mar}$ \\
\hline \multirow[t]{5}{*}{ Annual bluegrass } & Contr & 1.13 & 1.00 \\
\hline & $P c \times A b$ & 0.93 & 1.06 \\
\hline & $\mathrm{Pc}$ & 1.19 & 1.23 \\
\hline & Eth & 0.94 & 1.63 \\
\hline & Mes & 0.89 & 1.06 \\
\hline \multirow[t]{5}{*}{ Perennial ryegrass } & Contr & 1.26 & 1.04 \\
\hline & $P c \times A b$ & 1.35 & 0.89 \\
\hline & $\mathrm{Pc}$ & 1.42 & 1.21 \\
\hline & Eth & 1.75 & 1.37 \\
\hline & Mes & 1.00 & - \\
\hline \multirow[t]{5}{*}{ Kentucky bluegrass } & Contr & 1.19 & 0.80 \\
\hline & $P c \times A b$ & 1.12 & 1.06 \\
\hline & $\mathrm{Pc}$ & 1.43 & 1.00 \\
\hline & Eth & 1.37 & 1.04 \\
\hline & Mes & 0.94 & - \\
\hline
\end{tabular}

(-) because of the high efficacy of the product, we could not calculate the ratio; Feb - February; Mar - March; Apr - April.

Eth, ethephon; Mes, mesotrione; Pc, prohexadione calcium.

of application is also important when using herbicides on turfgrass, as their action is very specific (Elmore et al., 2013; Ferguson et al., 2016; Breeden et al., 2017).

In Experiment 1, the grasses were sprayed three times with growth regulators and twice with a systemic herbicide until the first mowing (in early March). The highest annual bluegrass in the first period was detected, when it was sprayed with $P_{c} \times A b$ and in the control treatment. The product $P c \times A b$ contains a mixture of $P$. fluorescens and A. brasilense, respectively. $P$. fluorescens was previously found to inhibit tiller formation in annual bluegrass (Kennedy, 2016), and the second species was found to have a positive effect on grass height (Braccini et al., 2012), especially on early growth (Hernaández-Esquivel et al., 2020). Presented findings can be also exposed in Experiments 1 and 2, as the impact of $P$. fluorescens and A. brasilense on annual bluegrass was detected. The lowest number of tillers at annual bluegrass sprayed with $P c \times A b$ was confirmed in Experiments 1 and 2. On the other hand, spraying with a product that contained P. fluorescens in the second and third growth periods resulted in a smaller number of tillers in the other two turfgrass species (perennial ryegrass and Kentucky bluegrass), but the number of tillers in both species was not different from that of the untreated control. Perennial ryegrass can grow very rapidly (Park et al., 2019), which can be confirmed in this study for the period up to the first mowing. Until the first mowing, a high growth intensity was also found in annual bluegrass, thus confirming the results of a previous study (Kennedy, 2016).

Different turfgrass species respond differently to spraying with growth regulators (March et al., 2013; Glab et al., 2020). Different responses of turfgrass species were also found for Mes, which was used as a positive control (Reicher et al., 2011). The activity of Mes was also influenced by the age of the turfgrasses, as $\mathrm{Yu}$ and McCulloough (2016) have shown that the activity of Mes is more efficient in younger lawns and that its activity is limited in more overgrown annual bluegrass. Mentioned findings were also confirmed in Experiment 1 , as the height of annual bluegrass that was sprayed twice with Mes still increased after the second mowing. Additionally, an increase in the number of tillers was also detected, when annual bluegrass was sprayed with Mes in Experiment 1. In the annual bluegrass with spraying only after the first mowing (Experiment 2), the plants were still viable at the end of the experiment (last three terms); however, they did not grow any further.

Kentucky bluegrass is thought to be resistant to Mes, as Yu and McCulloough (2016) found that damage to plants due to spraying with this synthetic herbicide was negligible. Based on the results of Experiments 1 and 2 , this claim cannot be confirmed, as we found a negative effect on the height of Kentucky bluegrass in both Experiments 1 and 2 after two sprays with Mes. In Experiment 2, we also found that the development of Kentucky bluegrass was stopped 4 days after mowing or 1 week after the second spraying with Mes. In Experiment 1, the development of Kentucky bluegrass sprayed with Mes was stopped 3 weeks after the second spraying. Given that the results of related research indicate the insensitivity of Kentucky bluegrass to Mes (Reicher et al., 2017), the excellent herbicidal action of this active substance on this turfgrass species can be attributed to the special sensitivity of the variety (Shortell et al., 2008).

Mes may adversely affect the growth of perennial ryegrass (McCurdy et al., 2008), which was also confirmed in our study. In Experiment 1, a decrease in the height of the perennial ryegrass was recorded on $7^{\text {th }}$ April or 6 weeks after the second spraying. In 
the development of perennial ryegrass, the greatest reduction in tillers was found 2 days after the second (last) spraying with Mes, when the number of tillers reached approximately two per plant. There was a large number of tillers in both experiments for perennial grass, which produces its highest number of tillers in early summer, while the number of tillers of annual bluegrass is considered to be highest in early autumn (Brede and Duich, 1986). As previously mentioned (McCurdy et al., 2008; Goncalves et al., 2020), it is important not to use Mes under conditions of rapid turfgrass growth, because injuries of perennial ryegrass could occur. It has been also confirmed (Kennedy, 2016) and in the present study, that Mes can act against annual bluegrass but has limited specificity.

A large number of tillers per plant in both experiments for all three turfgrass species occurred for plants sprayed with the active substance Pc. Herewith, spraying with Pc has resulted in lower grass height, as previously described (McCurdy et al., 2008). This was also confirmed by the calculation of the average height ratio of grasses across three periods. Pc is thought to produce the lowest growth ratio for all three turfgrass species. Given that (Kennedy, 2016) mentions that annual bluegrass has its most intensive growth at the beginning of the growing season, spraying with Pc greatly inhibited the growth of annual bluegrass during the mentioned period. Spraying with Pc had the lowest effect on the growth of perennial ryegrass in the first period of both our experiments (McCurdy et al., 2008).

In Experiment 2, the weakest effect of Pc was found in the first period for Kentucky bluegrass, which was the highest of the three turfgrass species in the experiment. For all turfgrass species in our experiment, it is considered that in the Pc treatment, the plants were short with many tillers competing with each other for space. A plant that has faster growth takes up space faster and outcompetes slower growing plants (Beam and Askew, 2007; Masin and Macolino, 2016). Individual turfgrass species differ in morphological characteristics (Glab et al., 2020), such as the number of tillers. However, with the addition of growth regulators, these differences were even more obvious. The number of tillers in both experiments was highest for perennial ryegrass on $3^{\text {rd }}$ April, when we had already carried out six sprays in Experiment 1 and four sprays in Experiment 2. As detected, spraying with Pc or Pc results in the fastest overgrowth of perennial ryegrass, thus taking up space that could be occupied by annual bluegrass. Spraying football pitches with Pc may indirectly reduce the maintenance costs of turf by reducing the number of mowings, as this treatment affects all turfgrass species (Rademacher, 2016).

In the initial phase of Experiment 1, spraying with the Eth resulted in faster growth of the annual bluegrass than spraying with the active substance Pc. After six sprays with Eth, the development of the annual bluegrass stopped. After four sprays with Eth, the lowest number of tillers among all turfgrass species in the experiment was found for annual bluegrass. In Experiment 2, after five sprays with Eth, we confirmed the cessation of growth of annual bluegrass; the number of tillers was the lowest a week after the last spraying, followed by an increase in the tiller number. It has already been established that the mentioned active substance inhibits the development of tillers in annual bluegrass (Eggens et al., 1989). For the remaining two turfgrass species treated with Eth, the number of tillers was markedly higher, with perennial ryegrass having the highest values. We have demonstrated that knowing the population dynamics of tillers is very important, which was previously confirmed (De Lima et al., 2020).

\section{CONCLUSION}

In our study, we found that the invasiveness of annual bluegrass, the most important weed in turfgrass football pitches, can be reduced by repeatedly spraying turfgrass with Pc and P. fluorescens. Namely, the first substance influences the appearance of lower plants, and the second substance influences the formation of plants with fewer tillers. Such plants are less competitive with other species in turfgrass mixtures and have significantly less pronounced invasiveness. However, since the results of our research were obtained by spraying individual turfgrass species in greenhouse conditions, the combination of Pc and the bacterium P. fluorescens should be studied in turfgrass mixtures under natural conditions. By confirming their effectiveness in limiting the spread of annual bluegrass on football pitches, we could improve the appearance of the lawn on the pitches and significantly lower the cost of maintaining the turf, as on some pitches, managers replace the turfgrass due to their inability to limit the spread of annual bluegrass. By spraying annual bluegrass with Pc, we have achieved a comparable effect on plant height, regardless of whether the product was applied to a previously mown or un-mown turfgrass. In contrast, when spraying annual bluegrass after mowing with a product containing $P$. fluorescens, a higher inhibitory effect on tiller formation was observed compared to spraying before mowing.

\section{ACKNOWLEDGEMENT}

Jaka Rupnik, Boštjan Medved Karničar and Vid Žitko are acknowledged for their technical assistance. We would like to thank Karsia Ltd. for the product Baia, Metrob Ltd. for the product Regalis ${ }^{\circledR}$ Plus, Syngenta Agro Ltd. for the product Callisto ${ }^{\circledR} 480$ SC, and $\mathrm{Mr}$ Andrej Kocmur from CKC (Buenos Aires, Argentina) for the product Rhizoflo Premium. The study was performed at Development and Research Centre for Studying the Growth and Development of Agricultural Crops in Ljubljana (IC RRC-AG [IO0022-0481-001]). 


\section{FUNDING}

This research was conducted within Horticulture No. P4-0013-0481, a programme funded by the Slovenian Research Agency.

\section{AUTHORS CONTRIBUTIONS}

T.B. - formal analysis, writing original draft, writing review and editing. B.Z. - investigation, methodology, writing the original draft. M.V. - investigation, methodology. S.T. - supervision, validation, writing review and editing.

\section{CONFLICT OF INTEREST}

The authors declare no conflict of interest. The funders had no role in the design of the study, in the collection, analyses, or interpretation of data, in the writing of the manuscript or in the decision to publish the results.

\section{REFERENCES}

Aamlid, T. S., Thorvaldsson, G., Enger, F., And Pettersen, T. (2012). Turfgrass species and varieties for Integrated Pest Management of Scandinavian putting greens. Acta Agriculturae Scandinavica, Section B-Soil \& Plant Science, 62(suppl 1), 10-23.

BBCH MonOGRaPH (2018). Growth stages of mono - and dicotyledonous plants. U. Meier (Ed.). Quedlinburg, Germany: Julius Kühn-Institut (JKI), pp. 18-22.

Beam, J. B., And Askew, S. D. (2007). Fate of prohexadione calcium in annual bluegrass (Poa annua) and three turfgrasses. Weed Science, 55, 541-545.

Boyle, R. D., Corke, F. M. K., And Doonan, J. H. (2016). Automated estimation of tiller number in wheat by ribbon detection. Machine Vision and Application, 27, 637-646.

Braccini, A. D. E., Dan, L. G. D., Piccinin, G. G., Albrecht, L. P., Barbosa, M. C., And Ortiz, A. H. T. (2012). Seed inoculation with Azospirillum brasilense, associated with the use of bioregulators in maize. Revista Caatinga, 25, 58-64.

Brede, A. D., AND Duich, J. M. (1986). Plant interaction among Poa annua, Poa pratensis and Lolium perenne turfgrasses. Agronomy Journal, 78(1), 179-184.

Breeden, S. M., Brosnan, J. T., Mueller, T. C., Breeden, G. K., Horvath, B. J., and Senseman, S. A. (2017). Confirmation and control of annual bluegrass (Poa annua) with resistance to prodiamine and glyphosate. Weed Technology, 31, 111-119.

Brosnan, J. T., Elmore, M. T., and Bagavathiannan, M. V. (2020). Herbicide-resistant weeds in turfgrass: Current status and emerging threats. Weed Technology, 34, 424-430.

Cirera, J. (2013). Turfgrass culture. A technical handbook. Barcelona, Spain: Semillas Fito S.A.U.

Curk, M., Vidrih, M., Laznik, Ž., and Trdan, S. (2017). Turfgrass maintenance and management in soccer fields in Slovenia. Urban Forestry \& Urban Greening, 26, 191-197.

De Lima Veras, E.L., Dos Santos Difante, G., Chaves Gurgel, A. L., da Costa, A. B. G., Rodrigues, J. G., Costa, C. M., Emerenciano Neto, J. V.; De Gusmao Pereira, M., and Costa, P. R. (2020). Tillering and structural characteristics of Panicum cultivars in the Brazilian semiarid Region. Sustainability, 12, 3849, doi: 10.3390/su12093849.

Eggens, J. L., Wright, C. P. M., Murr, D. P., and Carey, K. (1989). The effect of ethephon on annual bluegrass and creeping bentgrass growth. Canadian Journal of Plant Science, 69, 1353-1357.

Elmore, M. T., Brosnan, J. T., Mueller, T. C., Horvath, B. J., Kopsell, D. A., and Breeden, G. K. (2013). Seasonal application timings affect dallisgrass (Paspalum dilatatum) control in tall fescue. Weed Technology, 27(3), 557-564.

Ferguson, J. C., Gaussoin, R. E., Eastin, J. A., Sousek, M. D., And Kruger, G. R. (2016). Efficacy of pre and postemergence herbicides on weed suppression in established turfgrass with a conventional and an ultra-low volume. Crop Protection, 89, 72-77.

Glab, T., Szewczyk, W., Gondek, K., Knaga, J., TomasiK, M., AND Kowalik, K. (2020). Effect of plant growth regulators on visual quality of turfgrass. Scientia Horticulturae, 26(1), doi: 10.1016/j. scienta.2020.109314.

Goncalves, C. G., Ricker, D. B., and Askew, S. D. (2020). Perennial ryegrass phytotoxicity increases with mesotrione rate and growth promoting environmental conditions. CROP Science, doi: $10.1002 / \csc 2.20407$.

Harding, P. D., And Raizada, M. N. (2015). Controlling weeds with fungi, bacteria and viruses: A review. Frontiers in Plant Science, 6, 659, doi: 10.3389/ fpls.2015.00659.

HernaÁndez-Esquivel, A., Castro-Mercado, E., Valencia-Cantero, E., Alexandre, G., and GarciaPinedA, E. (2020). Application of 3 lipopolysaccharides to promote early wheat plant growth and analysis of related biochemical responses. Frontiers in Sustainable Food Systems, 4, 579976, doi: 10.3389/ fsufs.2020.579976.

Jędrszczyk, E., Skowera, B., Kedzior, R., and Gaweda, M. (2017). The influence of ethephon application to processing tomato plants on yield structure in relation to weather conditions during growing period. Folia Horticulturae, 29(1), 75-81.

Kamal-Uddin, M., Juraimi, A. S., Begum, M., Ismail, M. R., Rahim, A. A., and Othman, R. (2009). Floristic composition of weed community in turf grass area of west peninsular Malaysia. International Journal of Agriculture and Biology, 11, 13-20.

Kennedy, A. C. (2016). Pseudomonas fluorescens strains selectively suppress annual bluegrass (Poa annua L.). Biological Control, 103, 210-217. 
Larsen, S. U., Kristoffersen, P., And Fischer, J. (2004). Turfgrass management and weed control without pesticides on football pitches in Denmark. Pest Management Science, 60(6), 579-587.

Manager's Guide to Natural Grass Football Pitches. (2021). FiFA. For the game. For the world. Retrieved from https://sportslabs.files.wordpress.com/2013/11/ guide-to-natural-grass-pitches_e.pdf.

March, S. R., Martins, D, and Mcelroy, J. S. (2013) Growth inhibitors in turfgrass. Planta Daninha, Vicosa-Mg, 31, 733-747.

Masin, R., And Macolino, S. (2016). Seedling emergence and establishment of annual bluegrass (Poa annua) in turfgrasses of traditional and creeping perennial ryegrass cultivars. Weed Technology, 30(1), 238-245.

Mccurdy, J. D., McElroy, J. C., Kopsell, D. A., SAms, C. E., And Sorochan, J. C. (2008). Effects of mesotrione on perennial ryegrass (Lolium perenne L.) concentrations under varying environmental conditions. Journal of Agriculture, Food and Chemistry, 56(19), 9133-9139.

Paikekari, A., Ghule, V., Meshram, P., and Raskar, V. B. (2016). Weed detection using image processing. International Research Journal of Engineering and Technology, 3(3), 1220-1222.

Park, B. S., Elmore, M. T., And Murphy, J. A. (2019). Using herbicides and perennial ryegrass to renovate turf dominated by annual bluegrass. Crop Forage \& Turfgrass Management, 5(1), doi: 10.2134/ cftm2019.01.0005.

Parra, L., Marin, J., Yousfi, S., Rincon, G., Mauri, P. V., AND Lloret, J. (2020). Edge detection for weed recognition in lawns. Computers and Electronics in Agriculture, 176, doi: 10.1016/j. compag.2020.105684.

Pedras, M. S. C., Ismail, N., Quail, J. W., AND Boyetchio, S. M. (2003). Structure, chemistry, and biological activity of pseudophomins $\mathrm{A}$ and $\mathrm{B}$, new cyclic lipodepsipeptides isolated from the biocontrol bacterium Pseudomonas fluorescens. Phytochemistry, 62, 1105-1114.

Petelewitz, P., Orlinski, P. M., And Baird, J. H. (2021). Suppression of annual bluegrass in creeping bentgrass putting greens using plant growth regulators. HortTechnology, 31(2), 155-165.
RADEMACHER, W. (2016). Chemical regulators of gibberellin status and their application in plant production. Annual Plant Review, 49, 359-403.

Reicher, Z. J., Weisenberger, D. V., Morton, D. E., Branham, B. E., AND Sharp, W. (2011). Fall applications of mesotrione for annual bluegrass control in Kentucky Bluegrass. Applied Turfgrass Science, 8(1), 1-10, doi: 10.1094/ATS-2011-0325-01-RS.

Reicher, Z., Souser, M., And Giese, M. (2017). Herbicide programs for annual bluegrass (Poa annua L.) control in Nebraska. Crop Forage \& Turfgrass Management, 3(1), 1-7, doi: 10.2134/cftm2015.0221.

Shortell, R. R., Hart, S. E., and Bonos, S. A. (2008). Response of Kentucky bluegrass (Poa pratensis L.) cultivars and selections to bispyribac-sodium herbicide. HortScience, 43(7), 2252-2255.

Skelton, J. J., Sharp, W., and Branham, B. E. (2012). Postemergence control of annual bluegrass with mesotrione in Kentucky Bluegrass. HortScience, 47(4), 522-526.

Statgraphics Centurion XVI. (2009). StatPoint Technologies Inc Warrenton. 2009, Va, USA. Retrieved from http://www.statgraphics.com.

Tilley, M. S., Heiniger, R. W., And Crozier, C. R. (2019). Tiller Initiation and its effects on yield and yield components in winter wheat. Agronomy Journal, 111, 1323-1332.

Tufgrass SEed. (2016). Semillas Fitó S.A.U. Retrieved from https://www.semillasfito.com/ media/3972/1512994322-0-1.pdf[Accessed 19.7.2011].

VenNer, K. A. (2011). Use of mesotrione for annual bluegrass (Poa annua L.) at cool-season turfgrass establishment. Master of Science Thesis. The State University of New Jersey, Usa, p. 66.

Yu, J., And Mcculloough, P. (2016). Growth stage influences mesotrione efficacy and fate in two bluegrass species. Weed Technology, 30, 524-532.

Yu, J., Sharpe, S. M., Schumann, A. W., and Boyd, N. S. (2019). Deep learning for image-based weed detection in turfgrass. European Journal of Agronomy, 104, 78-84.

Zhang, N., Han, L., Xu, L., and Zhang, X. (2018). Ethephon seed treatment impacts on drought tolerance of Kentucky bluegrass seedlings. HortTechnology, 28(3), 319-326.

Received: May 28, 2021; accepted: July 22, 2021. 